\title{
REVISIÓN, TRASCENDENCIA CONSTITUCIONAL Y MEMORIA HISTÓRICA
}

SABELA OUBIÑA BARBOLLA 
SUMARIO

1. INTRODUCCIÓN. 2. RECURSO DE REVISIÓN Y MEMORIA HISTÓRICA. 2.1. La revisión de la condena a muerte de Miguel Hernández. A. Antecedentes de hecho y solicitud de revisión. B. La opinión del ministerio fiscal sobre la solicitud de revisión. C. La respuesta de la Sala 5. a del Tribunal Supremo. D. El incidente de nulidad de actuaciones. 2.2. La supuesta falta del presupuesto objetivo del proceso de revisión y la Ley de Memoria Histórica. 3. EXAMEN DEL ATS, SALA 5. ${ }^{a}$ DE 21 DE FEBRERO DE 2011 DESDE EL PRISMA DE LOS DERECHOS FUNDAMENTALES. 3.1. El derecho a la tutela judicial efectiva en su vertiente de acceso al proceso y a una interpretación favor actionis. 3.2. El derecho a la tutela judicial efectiva en su vertiente del derecho a una resolución fundada en derecho. 3.3. El derecho a la presunción de inocencia. 4. EL FONDO DEL RECURSO DE REVISIÓN Y LOS HECHOS Y PRUEBAS ALEGADOS COMO NUEVOS AL OBJETO DE LA REVISIÓN DE LA CONDENA FIRME. 5. LA TRASCENDENCIA CONSTITUCIONAL DE LA DEMANDA DE AMPARO. 6. CONSIDERACIONES FINALES. 


\title{
REVISIÓN, TRASCENDENCIA CONSTITUCIONAL Y MEMORIA HISTÓRICA
}

\author{
SABELA OUBIÑA BARBOLLA ${ }^{1}$ \\ Profesora visitante Doctora de Derecho Procesal \\ Universidad Carlos III Madrid/Instituto Alonso Martínez de Justicia \\ y Litigación
}

\section{INTRODUCCIÓN}

La Sala 5. ${ }^{a}$ del TS denegó a la familia del poeta la autorización para interponer el recurso de revisión ${ }^{2}$ [Auto de 21 de febrero de $2011^{3}$ (núm. rec. 54/2010)]

\footnotetext{
1 Agradezco enormemente los comentarios de los dos revisores anónimos que han contribuido a mejorar el artículo porque todo siempre es mejorable. El artículo además ha sido corregido y modificado mientras me encontraba realizando una estancia de investigación de enero a junio de 2013 en la Facultad de Derecho de la Universidad de Birmingham; por eso, también quiero agradecer al Institute for Judicial Administration y a su directora la Dra. Marianne Wade y el resto de compañeros e investigadores las opiniones que me han dado al explicarles este caso tan particular. La idea de este artículo nació a partir de la ponencia «La nulidad de las sentencias franquistas ante los tribunales españoles: el caso Miguel Hernández», en el Seminario Los derechos de las víctimas del franquismo dirigido por el Dr. Rafael Escudero y la Dra. Carmen Pérez organizado por el grupo de investigación Derecho y Memoria que dirige el Dr. José María Sauca, en la Universidad Carlos III de Madrid. La estancia de investigación citada se efectuó entre otros, gracias, al apoyo del proyecto de investigación nacional TRANSDATPENAL del Ministerio de Ciencia e Innovación, referencia DER 2011/28282.

${ }^{2}$ Ilustrativo en general sobre la problemática revisión de estas condenas, vid. TERRADILLOS BOSOCO, «La revisión del pasado y la Ley de Memoria Histórica», Revista penal, núm. 25, 2010, pp. 151-166. VERGARA LACALLE, «La Ley de Memoria Histórica: ¿cuentas pendientes? Sobre la revisión judicial de las condenas dictadas por motivos políticos o sin las debidas garantías durante la Guerra Civil y la Dictadura», Justicia: revista de derecho procesal, núm. 2-4, 2011, pp. 177-230.

3 RJ $2011 \backslash 1291$.
} 
escudándose en una supuesta falta del presupuesto objetivo del recurso de revisión. La Sala 5. ${ }^{a}$ entiende que la sentencia de condena firme, cuya nulidad se pide, no existe en el mundo jurídico desde que la Ley de Memoria Histórica reconociese y declarase que las sentencias que se dictaron entonces fueron radicalmente injustas e ilegítimas por vicios de fondo y forma.

La familia de Miguel Hernández interpuso, frente a dicho auto, incidente de nulidad de actuaciones por vulneración del contenido esencial del derecho a la tutela judicial efectiva (art. 24.1 CE) en lo que al derecho de acceso al proceso y a una interpretación favor actionis se refiere, así como el derecho a una resolución fundada en la normativa vigente. La Sala 5. ${ }^{a}$ del TS mantuvo, sin embargo, su criterio y desestimó también el incidente de nulidad de actuaciones (vid. ATS, Sala 5. ${ }^{a} 15$ de junio de 2011).

Agotados todos los medios de impugnación previstos por las normas procesales dentro de la vía judicial, a finales de septiembre de 2010, la familia de Miguel Hernández interpuso recurso de amparo ante el Tribunal Constitucional por la vía del art. 44 de la Ley Orgánica del Tribunal Constitucional ${ }^{4}$ (en adelante LOTC), es decir, por violación de diversos derechos fundamentales con origen inmediato y directo en un acto u omisión de un órgano judicial. Casi un año más tarde y con apenas cuatro líneas, la sección $4 .^{a}$ del Tribunal Constitucional inadmitió a trámite la demanda mediante una providencia de 17 de septiembre de 2012 con base en «la manifiesta inexistencia de un derecho fundamental tutelable en amparo, violación que, de acuerdo con el art. 44.1 LOTC, es condición para que este Tribunal pueda ejercer dicha tutela».

$\mathrm{El}$ asunto esconde diversas cuestiones procesales y constitucionales que merecen y exigen un análisis separado porque si no es muy fácil que los argumentos se confundan y diluyan unos con otros. Precisamente para intentar evitarlo, hemos dividido el trabajo de acuerdo con los problemas que se suscitan. El trabajo comienza necesariamente con una recapitulación del iter procesal del caso que nos ocupa y sus detalles, al que sigue inmediatamente una exposición en tres actos. Primero, sobre el discutible razonamiento de la Sala 5. ${ }^{a}$ del TS para denegar la autorización para la interposición del recurso de revisión y si la respuesta de la Sala 5. ${ }^{a}$ del TS vulneró, o no, algunas dimensiones del contenido esencial del derecho a la tutela judicial efectiva de la solicitante de la revisión. Segundo, si los hechos aducidos por la familia de Miguel Hernández como base para la revisión merecen o no la consideración de hecho nuevo como punto de partida de la revisión. Y, por último, la trascendencia constitucional que tendrían las lesiones de derechos fundamentales producidas como para que el Tribunal Constitu-

\footnotetext{
${ }^{4}$ Ley Orgánica 2/1979, de 3 de octubre, del Tribunal Constitucional.
} 
cional hubiera admitido, al menos, a trámite la demanda y resuelto sobre el fondo; y, ello con independencia de que la sentencia fuera estimatoria o desestimatoria.

\section{RECURSO DE REVISIÓN Y MEMORIA HISTÓRICA}

\subsection{La revisión de la sentencia de condena a muerte de Miguel Hernández}

\section{A. Antecedentes de hecho y solicitud del recurso de revisión}

El punto de partida se remonta al 18 de enero de 1940, fecha en la que el Consejo de Guerra núm. 5 de Madrid condenó a muertes, en un procedimiento sumarísimo de urgencia, a Miguel Hernández como autor (directo y voluntario) de un delito de adhesión a la rebelión sancionado en el párrafo $2 .^{\circ}$ del entonces art. 238 Código de Justicia Militar ${ }^{6}$. La sentencia declaró probado ${ }_{(j}$ ) que el procesado (...), de antecedentes izquierdistas se incorporó voluntariamente en los primeros días del Alzamiento Nacional al 5. Regimiento de Milicias pasando más tarde al Comisariado

${ }^{5}$ La pena de muerte le fue posteriormente conmutada por la de reclusión de 30 años durante la que Miguel Hernández murió en la cárcel el 28 de marzo de 1942 al haber contraído tuberculosos por las malas condiciones padecidas durante su reclusión.

${ }^{6}$ El Código de Justicia Militar se aprobó por Real Decreto de 27 de septiembre de 1890 y estuvo vigente hasta la ley de 17 de julio de 1945 que lo derogó y estableció un nuevo código. El texto del Código de Justicia Militar de 1890 se publicó en la Gaceta de Madrid, núm. 278-279, los días 4 a 11 de octubre de 1980. El texto original disponible online a través de las bases de datos del BOE en http://www.boe.es/datos/pdfs/BOE/1890/279/A00074-00076.pdf. El Capítulo primero, del Título VI llevaba por rúbrica Delitos contra la seguridad del Estado y del Ejército; y, concretamente los arts. 237-242 se referían al delito de rebelión. Así y, de acuerdo con el art. 237, eran «reos del delito de rebelión militar los que se alcen en armas contra la constitución del Estado, contra el Rey, los Cuerpos Colegisladores o el Gobierno legítimo, siempre que lo verifiquen concurriendo alguna de las circunstancias siguientes: $1 .{ }^{a}$ Que estén mandados por militares, ó que el movimiento se inicie, sostenga ó auxilie por fuerzas del Ejército. 2. ${ }^{a}$ Que formen partida militarmente organizada o compuesta de 10 ó más individuos. 3. ${ }^{a}$ Que formen partida en menor número de 10, sí en distinto territorio de la Nación existen otras partidas ó fuerzas que se proponen el mismo fin. $4 .^{a}$ Que hostilicen á las fuerzas del Ejército antes o después de haberse declarado el estado de guerra». A continuación el art. 238, en lo que a las penas se refiere, preveía que los reos de rebelión militar fueran castigados: $« 1 .{ }^{\circ}$ Con la pena de muerte, el Jefe de la rebelión y el de mayor empleo militar, ó más antiguo, si hubiere varios del mismo que se pongan á la cabeza de la fuerza rebelde de cada cuerpo y de la de cada compañía, escuadrón, batería, fracción ó grupo de estas unidades. $2 .{ }^{\circ}$ Con la de reclusión perpetua á muerte los demás no comprendidos caso anterior, los que se adhieran á la rebelión en cualquier forma que lo ejecuten y los que valiéndose del servicio oficial que desempeñen, propalen noticias ó ejecuten actos que puedan contribuir á favorecerla». 
Político de la 1. 'Brigada de Choque e interviniendo entre otros bechos en la acción contra el Santuario de Santa María de la Cabeza. Dedicado a actividades literarias era miembro activo de la Alianza de intelectuales antifascistas, babiendo publicado numerosas poesías y crónicas, y folletos, de propaganda revolucionaria y de excitación contra las personas de orden y contra el Movimiento Nacional, haciéndose pasar por el poeta de la revolución».

El 13 de julio de 2010 su nieta promovió recurso de revisión ante la Sala 5. ${ }^{a}$ del TS alegando que después de aquella sentencia de condena se conocieron hechos y/o pruebas que evidencian su error. La Ley Procesal Militar ${ }^{7}$ prevé que habrá lugar al recurso de revisión contra sentencias firmes, entre otros motivos ${ }^{8}$, cuando después de dictada sentencia condenatoria se conociesen pruebas indubitadas suficientes a evidenciar el error del fallo por ignorancia de las mismas (art. 328). Un motivo de revisión, que la Ley de Enjuiciamiento Criminal (en adelante LECrim ${ }^{9}$ ) recoge en términos muy similares, aunque no idénticos, al establecer que podrá

7 Ley Orgánica 2/1989, de 13 de abril.

${ }^{8}$ La LPM prevé también otros cinco motivos del recurso de revisión: 1) Cuando hayan sido condenadas dos o más personas en virtud de sentencias contradictorias por un mismo hecho que no haya podido ser cometido más que por una sola; 2) Cuando haya sido condenado alguno como responsable de la muerte de una persona cuya existencia se acredite después de la fecha de la sentencia condenatoria. 3) Cuando haya sido condenada una persona en sentencia cuyo fundamento fuera: un documento o testimonio declarados después falsos por sentencia firme en causa criminal, la confesión del reo arrancada por violencia o coacción o cualquier otro hecho punible ejecutado por un tercero, siempre que tales extremos resulten también declarados por sentencia firme en procedimiento seguido al efecto. A estos fines podrán practicarse cuantas pruebas se consideren necesarias para el esclarecimiento de los hechos controvertidos en el procedimiento, anticipándose aquéllas que por circunstancias especiales pudieran luego dificultar y hasta hacer imposible la sentencia firme base de la revisión; 4) Cuando haya sido penada una persona en sentencia dictada por el Tribunal y alguno de sus miembros fuere condenado por prevaricación cometida en aquella sentencia, o cuando en la tramitación de la causa se hubiere prevaricado en resolución o trámite esencial de influencia notoria a los efectos del fallo; 5) Cuando sobre los propios hechos hayan recaído dos sentencias firmes y dispares dictadas por la misma o por distintas jurisdicciones.

9 La LECrim dispone también que habrá lugar al recurso de revisión contra las sentencias firmes: 1) Cuando estén sufriendo condena dos o más personas, en virtud de sentencias contradictorias, por un mismo delito que no haya podido ser cometido más que por una sola. 2) Cuando esté sufriendo condena alguno como autor, cómplice o encubridor del homicidio de una persona cuya existencia se acredite después de la condena. 3). Cuando esté sufriendo condena alguno en virtud de sentencia, cuyo fundamento haya sido un documento o testimonio declarados después falsos por sentencia firme en causa criminal, la confesión del reo arrancada por violencia o exacción, o cualquier hecho punible ejecutado por un tercero, siempre que los tales extremos resulten también declarados por sentencia firme en causa seguida al efecto. A estos fines podrán practicarse todas cuantas pruebas se consideren necesarias para el esclarecimiento de los hechos controvertidos en la causa, anticipándose aquellas que por circunstancias especiales pudieran luego dificultar y hasta hacer imposible la sentencia firme, base de la revisión. 
solicitarse la revisión cuando después de la sentencia sobrevenga el conocimiento de nuevos hechos o de nuevos elementos de prueba, de tal naturaleza que evidencien la inocencia del condenado (art. 954.4..$^{\circ}$ ).

En concreto, la nieta del poeta promueve el recurso de revisión alegando la concurrencia de tres hechos nuevos:

1. Pruebas y diligencias practicadas en un proceso penal seguido ante el Tribunal Militar de Orihuela y que se han conocido con posterioridad.

Con posterioridad a la sentencia que condenó a muerte a Miguel Hernández se conoció que en las mismas fechas (1939) un Juzgado Militar de Orihuela tramitaba otro sumario (el núm. 4.487) en el que se practicaron pruebas y diligencias que evidenciaban la inocencia de Miguel Hernández y que no fueron conocidas por el Consejo de Guerra núm. 5 de Madrid que le condenó a muerte. En especial, los avales personales y testimonios ${ }^{10}$ de personas relevantes de la dictadura que certificaron entonces que Miguel Hernández era una persona de garantía y orden, de intachables antecedentes y buena conducta cívica. Pruebas y diligencias que si se hubieran conocido por el Consejo de Guerra núm. 5 de Madrid hubieran llevado, según la recurrente, a la absolución de Miguel Hernández bien por probarse su inocencia, o por haberse introducido la duda razonable sobre su culpabilidad.

\section{La Ley de Memoria Histórica ${ }^{11}$ (en adelante LMH).}

La LMH que, entre otras cosas, reconoce y declara (arts. 2 y 3) el carácter radicalmente injusto e ilegítimo por vicios de forma y de fondo de todas las

${ }^{10}$ En ese otro sumario constaba una carta exculpatoria escrita por Juan Bellod, Jefe de Falange de Valencia, que aseguraba conocer a Miguel Hernández desde su niñez y describe al poeta como una persona de «inmejorables antecedentes, generosos sentimientos y honda formación religiosa y humana» y asegura que su «excesiva sensibilidad y temperamento poético» pudo llevarle a actuar «por apasionamiento». El falangista destacaba que: «En los primeros tiempos del Movimiento me visitó repetidas veces en la cárcel de Jesús y María en la que a la sazón me encontraba detenido, constándome que hizo cuanto estuvo en su mano para evitar que fuese paseado». Bellod concluía: «No le creo capaz de haber intervenido en hecho alguno delictivo, estimando que su producción literaria en las publicaciones rojas obedecía a coacciones o incluso a imperativos de su pasión cambiada de signo por la falaz propaganda marxista (...) No le creo, en lo fundamental, enemigo de nuestro Glorioso Movimiento con cuyos principios, una vez conocidos en la reveladora verdad de nuestra doctrina hecha actuación gloriosa, le considero identificado».

11 A la Ley 52/2007, de 26 de diciembre, se le ha denominado generalmente el nombre de Ley de Memoria Histórica, pero su título es el de Ley por la que se reconocen y amplían derechos y se establecen medidas en favor de quienes padecieron persecución o violencia durante la guerra civil y la dictadura. 
condenas y sanciones dictadas durante la Guerra Civil y la Dictadura por razones políticas, ideológicas, de creencia religiosa, por defender la legalidad institucional anterior, por procurar el restablecimiento de un régimen democrático en España o, simplemente, por intentar vivir conforme a opciones amparadas por derechos y libertades hoy reconocidos por la CE.

Además, la LMH no sólo declara injustas esas condenas que — como la de Miguel Hernández — se produjeron por razones ideológicas o políticas durante la dictadura, sino también la ilegitimidad de origen y ejercicio de los tribunales que las dictaron.

3. La declaración de reparación y reconocimiento personal, regulada en el art. 4 de la LMH, concedida a favor de Miguel Hernández.

Esta declaración de reparación es un documento oficial, expedido por el Ministerio de Justicia, en el que se reconoce que Miguel Hernández fue condenado mediante una sentencia injusta; se trata, pues, de un reconocimiento explícito por parte del Estado español de la injusticia de la condena.

B. La opinión del Ministerio Fiscal sobre la solicitud de revisión

El Ministerio Fiscal se opuso a la autorización de la interposición del recurso de revisión porque ninguno de los motivos alegados por la promovente podían considerarse hechos nuevos al objeto de la interposición del recurso de revisión.

En lo que a las pruebas y diligencias practicadas en el (otro) procedimiento que se había seguido ante el Tribunal Militar de Orihuela, el Ministerio Fiscal alegó que los referidos avales personales no constituyen verdaderos elementos probatorios y menos aún pruebas indubitadas pues no pasan de ser meras opiniones personales prestadas por amigos del imputado cuya autoridad o solvencia no consta en absoluto.

En lo que al segundo de los argumentos se refiere el Ministerio Fiscal adujo que la promulgación y contenido de la LMH no puede reputarse como un becho nuevo al objeto de la interposición del recurso de revisión.

Con base en lo anterior, el Ministerio Fiscal solicitó se denegase la autorización para la interposición de la revisión. Ahora bien, no debe menospreciarse aquí un matiz importante. $\mathrm{Y}$ es que el Ministerio Fiscal concluía este primer 
dictamen ${ }^{12}$ alegando que el que la Sala $5 .{ }^{a}$ del TS rechazase la autorización preceptiva para la interposición del recurso de revisión no era óbice para que en el mismo pronunciamiento la Sala declarase también, de acuerdo con el contenido de las declaraciones de la LMH, la nulidad de pleno derecho e inexistencia jurídica de la resolución recurrida. Este inciso pequeño, pero singularmente importante ${ }^{13}$, choca con el razonamiento jurídico utilizado finalmente, como veremos en el siguiente punto, por la Sala $5{ }^{a}$ del TS.

\section{La respuesta de la Sala 5. ${ }^{a}$ del Tribunal Supremo}

La Sala 5. ${ }^{a}$ del TS ${ }^{14}$ denegó a la nieta de Miguel Hernández la preceptiva autorización para interponer el recurso de revisión en su primer trámite; un dato esencial que es importante subrayar porque la Sala 5. ${ }^{a}$ no desestima el recurso de revisión en el fondo, sino que no entra si quiera a conocer los motivos alegados por

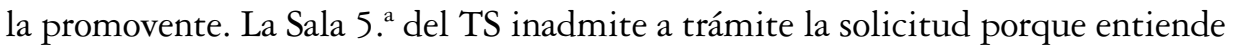
que falta el presupuesto objetivo del recurso de revisión. A juicio de la Sala la sentencia de condena firme, cuya nulidad se pide, ya no existe porque la LMH ha declarado que es radicalmente injusta e ilegítima por vicios de fondo y forma, y carece actualmente de cualquier vigencia jurídica.

La Sala 5. ${ }^{a}$ del TS se separa así también del criterio del Ministerio Fiscal porque recordemos que para éste la autorización debía denegarse porque ningu-

${ }^{12} \mathrm{Al}$ menos en este momento porque más adelante se opone al incidente de nulidad de actuaciones uniéndose al razonamiento jurídico de la Sala $5 .{ }^{a}$ del TS.

${ }^{13}$ Contradicción que, al menos, en este primer trámite parece menor de aquella en la que, como veremos a continuación, incurre el propio Tribunal Supremo en el auto de inadmisión. Sea como fuere, el Ministerio Fiscal se había negado ya anteriormente a solicitar la nulidad de la sentencia que condenó a Luis Company i Jover. En aquél caso, el Fiscal General del Estado aprobó un Decreto de 5 de abril de 2010 en el que, tras la reunión de la Junta de Fiscales de Sala del TS el 25 de marzo de 2010, acordaba «reconocer que las sentencias dictadas por el Tribunal de Responsabilidades Políticas de Barcelona en fecha 13 de diciembre de 1939 y por el Consejo de Guerra de Oficiales Generales en fecha 14 de octubre de 1940 relativas al Presidente de la Generalitat de Cataluña D. Lluis Companys i Jover son inexistentes y nulas de pleno derecho sin que subsista actualmente apariencia alguna de legalidad ó validez de las mismas, al haber sido expulsadas del ordenamiento jurídico, por lo que resulta legalmente improcedente, por falta de objeto, la interposición del recurso de revisión ante el Tribunal Supremo». El texto integro puede consultarse en www.fiscal.es

${ }^{14} \mathrm{La}$ competencia de la jurisdicción militar en este caso merecería un epígrafe aparte que, sin embargo, resulta imposible abordar en estas breves líneas. Baste decir que La jurisdicción militar o castrense es la única jurisdicción especial prevista en nuestra CE. La jurisdicción militar está integrada en Poder Judicial pero con especialidades en cuanto a su personal jurisdiccional (jueces y magistrados) y el ámbito de los conflictos jurídicos que quedan sometidos a esta jurisdicción especial. 
no de los hechos alegados por la solicitante de la revisión constituía un becho nuevo que pudieran abrir la puerta de la revisión. Recordemos además que el Fiscal, al informar sobre la interposición del recurso de revisión, a pesar de oponerse a la admisión no encontraba obstáculo para que la Sala 5. e del TS declarase la nulidad de pleno derecho e inexistencia jurídica de la resolución recurrida de acuerdo con el contenido de las declaraciones de la LMH.

Por otro lado, la decisión de la Sala 5. del TS tampoco es unánime. En contra del criterio mayoritario, el magistrado Javier Juliani emitió un voto particular discrepante con la denegación de la autorización para interponer el recurso de revisión sin entrar a examinar si procedía autorizar su interposición con base en los motivos alegados por la nieta de Miguel Hernández.

El magistrado defiende que la LMH no excluye el derecho de quienes estén legítimamente interesados en promover la revisión de las sentencias a las que se refiere la ley; es decir, a que los legítimamente interesados puedan ${ }^{15}$ interponer y obtener, en caso de que concurra alguno de los supuestos legales previstos en la ley procesal para el proceso de revisión, la anulación judicial de aquellas sentencias en las que se constate la inocencia del condenado.

Según el voto particular, es constitucionalmente discutible deducir que falta el presupuesto objetivo del recurso de revisión (es decir, la sentencia firme de condena) de la declaración de injusticia e ilegitimidad de las condenas porque ello significaría cerrar para siempre la puerta de la revisión y, en su caso, anulación judicial, de las sentencias a que se refiere la LMH.

D. El incidente de nulidad de actuaciones

La familia de Miguel Hernández, disconforme con la decisión de la Sala 5. ${ }^{2}$ del TS, planteó incidente de nulidad de actuaciones (arts. 240 y 241 de la LOPJ) contra el ATS de 21 de febrero de $2011^{16}$ que denegó la autorización de la interposición del recurso de revisión.

El art. 241 de la LOPJ, de acuerdo con la redacción dada por la disposición

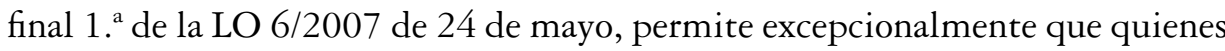
sean parte legítima, o hubieran debido serlo, puedan pedir por escrito que se declare la nulidad de actuaciones fundada en cualquier vulneración de un derecho fundamental de los referidos en el art. 53.2 CE, siempre que la vulneración no haya podido denunciarse antes de recaer resolución que ponga fin al proceso y

15 Además de la declaración administrativa de reparación y reconocimiento personal prevista en la ley.

16 RJ $2011 \backslash 1291$. 
siempre que dicha resolución no sea susceptible de recurso ordinario ni extraordinario. La LO 6/2007 modificó una vez más ${ }^{17}$ el incidente de nulidad de actuaciones con el objetivo de subrayar el protagonismo que corresponde a la jurisdicción ordinaria en la tutela de los derechos y libertades fundamentales. La LO 6/2007, de 24 de mayo, de reforma de la LOTC complementó la importante reforma en el trámite de admisión del amparo constitucional con la del incidente de nulidad de actuaciones, extendiéndolo a todos los casos en que se alegue la lesión de un derecho o libertad fundamental con independencia del derecho o la libertad concreta de que se trate. El incidente de nulidad se convierte así, en muchos casos, en un paso previo obligado antes de acudir al Tribunal Constitucional, para apurar como siempre ha debido ser la tutela de los derechos fundamentales en la jurisdicción ordinaria.

Volviendo sobre el incidente de nulidad que nos ocupa, la nieta de Miguel Hernández alegó que el Auto de 21 de febrero de 2011 de la Sala 5. ${ }^{a}$ del TS, que le había denegado la autorización para la interposición del recurso de revisión, vulneró su derecho a la tutela judicial efectiva sin indefensión en cuanto derecho de acceso al proceso, a una interpretación favor actionis y a una resolución fundada en la normativa vigente que, junto con otras dimensiones, forman parte del contenido esencial del art. 24.1 CE.

El incidente de nulidad de actuaciones era el instrumento procesal idóneo para el restablecimiento del derecho fundamental teniendo en cuenta, como exige el art. 241 LOPJ, que la vulneración no había podido denunciarse con anterioridad y que el auto recurrido (Auto de 21 de febrero de 2011 de la Sala

${ }^{17}$ LO 5/1997, de 4 de diciembre, modificó el art. 240 de la LOPJ con un cambio en el apartado segundo y añadiendo dos nuevos apartados [tercero y cuarto]. LO 13/1999, de 14 de mayo, volvió a modificar el art. 240 de la LOPJ en sus apartados tercero y cuarto. El contenido del art. 240 de la LOPJ pasó a un nuevo art. 241 en la LO 19/2003, de 23 de diciembre también con una nueva redacción. Sobre las distintas redacciones de los arts. 240 y 241 de la LOPJ, DE LA OLIVA SANTOS, Introducción al Derecho Procesal (con VEGAS TORRES y DÍEZ-PICAZO GIMÉNEZ, I.), Madrid, Editorial Centro de Estudios Ramón Areces S. A, 1999, pp. 352-353. Antes de las reformas previas de la LOPJ (LO 5/1997, la LO 13/1999, y la LO 19/2003) en esta materia el único remedio frente a las resoluciones judiciales firmes, (fuera del caso de la audiencia al rebelde y con el objeto que le es propio), era interponer directamente el amparo constitucional. Las reformas trataron de evitar la proliferación de «recursos» de amparo directos o per saltum, vid. SSTC 178/2002, FJ 4; 165/2002FJ 3; 86/200, FJ 2; 211/1999, FJ 2; 169/1999, FJ 2; 108/1999, FJ 2. Un buen repaso también en CARRASCO DURÁN, Los procesos para la tutela judicial de los derechos fundamentales, Madrid, CEPC, 2002, pp. 489 y ss. Sobre las reformas DOIG DÍAZ, «Análisis del nuevo incidente de nulidad de actuaciones en la Ley Orgánica 6/2007 de reforma del art. 241 LOPJ», Diario La Ley, núm. 6889, 22 de febrero, 2008, Año XXIX, ref. D-53, La Ley 1116/2008, pp. 2-5. 
5. a del TS) que había denegado la autorización para la interposición de la revisión, no era susceptible de recurso ordinario u extraordinario.

A finales de septiembre de 2011, la nieta de Miguel Hernández interpuso recurso de amparo ante el Tribunal Constitucional frente a la denegación de la interposición de recurso de revisión (ATS, Sala 5.a de 21 de febrero de 2011) y la sucesiva inadmisión del incidente de nulidad de actuaciones (ATS, Sala 5. a de 15 de junio de 2011) por vulneración del derecho a la tutela judicial efectiva (art. 24.1 CE) en su vertiente de acceso al proceso; a una interpretación pro actione favorable al ejercicio de la acción y del derecho a una resolución amparada en la normativa vigente; así como indirectamente al derecho a la presunción de inocencia (art. 24.2 CE). Estas lesiones son las que se alegaron primero en el incidente de nulidad de actuaciones $\mathrm{y}$, se repitieron más tarde en la demanda de amparo al no haber resultado tuteladas por la Sala 5. del TS que desestimó el incidente de nulidad de actuaciones.

En los epígrafes que siguen intentaremos ahondar en la discutible deducción que extrae la Sala 5.a del TS, así como en las diferentes vulneraciones que se habrían producido con la denegación de la autorización de la interposición de la revisión.

\subsection{La supuesta falta del presupuesto objetivo del proceso de revisión y la Ley de Memoria Histórica}

La Sala 5. a del TS deniega la autorización para la interposición del recurso de revisión en el auto de 21 de febrero de 2011 basándose en la «inexistencia de presupuesto objetivo previo al ser la sentencia cuya revisión se solicita radicalmente injusta y haber sido declarada ilegítima por la LMH, careciendo actualmente de cualquier vigencia jurídica». Con ello, la Sala 5. del TS viene a decir me pides algo que ya tienes; o lo que es lo mismo, me pides la nulidad de una sentencia de condena a muerte que no te puedo dar porque carece de vigencia que es lo que significa que declaración que efectúa la $L M H$ de que estas condenas son injustas e ilegítimas.

Rebatir o, al menos discutir el anterior razonamiento, exige preguntarnos ¿si en algún momento se ha declarado que la condena es nula?; y, en caso negativo ¿si es lo mismo nulidad que ilegitimidad, injusticia y carencia de vigencia jurídica?

La LMH no recoge declaración de nulidad alguna. El término nulo, nula, nulidad, no aparece ${ }^{18}$ en la LMH. Y, además, la carencia de vigencia jurídica que

18 Para ser exactos, la LMH si recoge la palabra nulidad, pero sólo una sola vez y lo hace en otro sentido para referirse a la nulidad matrimonial; concretamente en el art. 10.2 LMH a propósito del reconocimiento a favor de personas fallecidas en defensa de la democracia durante el 
esgrime la Sala 5. ${ }^{a}$ del TS está recogida en la Exposición de Motivos de la LMH, pero no en el articulado de la ley.

El art. 2 de la LMH establece en sus dos primeros apartados:

1. Como expresión del derecho de todos los ciudadanos a la reparación moral y a la recuperación de su memoria personal y familiar, se reconoce y declara el carácter radicalmente injusto de todas las condenas, sanciones y cualesquiera formas de violencia personal producidas por razones politicas, ideológicas o de creencia religiosa, durante la Guerra Civil, así como las sufridas por las mismas causas durante la Dictadura.

2. Las razones a que se refiere el apartado anterior incluyen la pertenencia, colaboración o relación con partidos políticos, sindicatos, organizaciones religiosas o militares, minorías étnicas, sociedades secretas, logias masónicas y grupos de resistencia, así como el ejercicio de conductas vinculadas con opciones culturales, lingüísticas o de orientación sexual (...).

Y el art. 3 de la LMH:

1. Se declara la ilegitimidad de los tribunales, jurados y cualesquiera otros órganos penales o administrativos que, durante la Guerra Civil, se hubieran constituido para imponer, por motivos políticos, ideológicos o de creencia religiosa, condenas o sanciones de carácter personal, así como la de sus resoluciones.

2. Por ser contrarios a Derecho y vulnerar las más elementales exigencias del derecho a un juicio justo, se declara en todo caso la ilegitimidad del Tribunal de Represión de la Masonería y el Comunismo, el Tribunal de Orden Público, así como los Tribunales de Responsabilidades Políticas y Consejos de Guerra constituidos por motivos políticos, ideológicos o de creencia religiosa de acuerdo con lo dispuesto en el art. $2 \mathrm{LMH}$.

3. Igualmente, se declaran ilegitimas, por vicios de forma y fondo, las condenas y sanciones dictadas por motivos políticos, ideológicos o de creencia por cualesquiera tribunales $u$ órganos penales o administrativos durante la Dictadura contra quienes defendieron la legalidad institucional anterior, pretendieron el restablecimiento de un régimen democrático en España o intentaron vivir conforme a opciones amparadas por derechos $y$ libertades boy reconocidos por la Constitución.

Por tanto, de las declaraciones convenientemente genéricas y abstractas de los arts. 2 y 3 de la LMH lo único que puede concluirse estrictamente en este caso es: a) La ilegitimidad del Consejo de Guerra núm. 5 que durante la Dicta-

período comprendido entre el 1 de enero de 1968 y 31 de diciembre de 1977 cuando señala «2. Serán beneficiarios de la indemnización a que se refiere el apartado primero de este artículo los hijos y el cónyuge de la persona fallecida, si no estuviere separado legalmente ni en proceso de separación o nulidad matrimonial, o la persona que hubiere venido conviviendo con ella de forma permanente con análoga relación de afectividad a la del cónyuge durante, al menos, los dos años inmediatamente anteriores al momento del fallecimiento, salvo que hubieren tenido descendencia en común, en cuyo caso bastará la mera convivencia». 
dura condenó a Miguel Hernández a muerte; b) La injusticia de la sentencia y demás resoluciones dictadas por ese Consejo de Guerra en aquel proceso sumario y urgente; c) La radical injusticia e ilegitimidad de la condena a muerte de Miguel Hernández con origen en razones políticas, ideológicas y/o de creencia religiosa (...).

Sin embargo, la Sala $5 .^{a}$ del TS deniega a la solicitante la autorización para la interposición del recurso de revisión basándose en la supuesta falta del presupuesto objetivo previo, es decir, de la sentencia de condena cuya revisión se pedía porque esa sentencia carece de vigencia jurídica y ya no está en el mundo jurídico desde que la LMH declarase su injusticia e ilegitimidad.

Con el debido respeto, en términos estrictos es muy discutible que una declaración de ilegitimidad y/o de injusticia sea lo mismo, o pueda equipararse, a una declaración de nulidad. Por eso, no deberían atribuirse los efectos de la declaración de nulidad a una declaración genérica de injusticia e ilegitimidad.

La Sala 5. ${ }^{a}$ del TS confunde en esa disquisición, como ha escrito el profesor ASENCIO MELLADO ${ }^{19}$, la validez con la vigencia jurídica y la nulidad con la ineficacia, la injusticia y la ilegitimidad. Una sentencia, o en general una resolución judicial, puede ser válida o nula, pero no se trata de que tenga o carezca de vigencia jurídica. La validez o, al contrario, la nulidad son conceptos que cabe atribuir a las resoluciones judiciales, mientras que la vigencia jurídica se refiere a los textos y disposiciones legales.

Para la Sala 5. ${ }^{a}$ del TS una sentencia válida y eficaz puede dejar de serlo, aunque no sea declarada nula, al declarase su injusticia e ilegitimidad porque entonces pasa a carecer de vigencia jurídica. El concepto de vigencia se superpone, según la tesis de la Sala $5 .^{a}$ del TS, al de la validez y la eficacia, instituyendo así una nueva categoría jurídica de los actos procesales de contornos no conocidos hasta ahora.

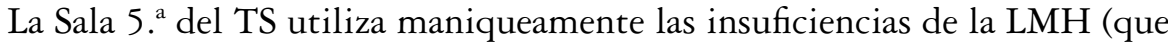
desde luego tiene y muchas), su meditada indefinición, su calculada ambigüedad para inadmitir la autorización necesaria para la interposición del recurso de revi-

19 ASENCIO MELLADO, «La revisión de la condena del poeta Miguel Hernández». MANJÓN-CABEZA OLMEDA, «2012: Las posibilidades legales de la memoria histórica», Revista Electrónica de Ciencia Penal y Criminología, RECPC 14-12, Disponible en http://criminet.ugr.es/ recpc/14/recpc14-12.pdf, pp. 33-34. Vid. también la opinión de JIMÉNEZ VILLAREJO en diversos foros. «Jiménez Villarejo ve un "dislate" el fallo del Supremo sobre la condena de Miguel Hernández», El País, 25 de marzo de 2011; en el caso Companys, «Jiménez Villarejo ve "fraude de ley" en la decisión del Fiscal sobre Companys», El País, 26 de marzo de 2011. ESCUDERO ALDAY ha hecho un seguimiento de los casos en diversos artículos en el diario Público, vid. 11 de octubre de 2012. 
sión. Cualquiera de las expresiones que finalmente recogió la LMH fueron fruto de negociaciones políticas complicadas y discutibles. Por ejemplo, la ilegitimidad que finalmente se plasmó en la LMH no convencía a todos, pero el PSOE sólo aceptó recoger este término. En realidad, como recuerda TAMARIT SUMALLA $^{20}$, Izquierda Unida, los partidos independistas catalanes y un significado número de ONGs reclaman que la ley recogiera una declaración de que tales juicios y decisiones eran nulos. En situaciones similares, otros ordenamientos jurídicos han optado por otras fórmulas menos controvertidas. Así, la ley alemana reguló más cuidadosa y detalladamente ${ }^{21}$ los casos en que las condenas de prisión dictadas durante el periodo comprendido entre el 8 de mayo de 1945 y el 2 de octubre de 1990 en la Alemania del Este ${ }^{22}$ podrían declararse judicialmente nulas por contrarias al Estado de Derecho cuando el fallo hubiera sido fruto de una persecución política ${ }^{23}$ o si la pena impuesta era totalmente desproporcionada con el delito cometido sentencias) y el procedimiento judicial para hacer tal declaración.

Ahora bien, por muchas críticas que puedan hacerse al legislador español por la vaguedad de la $\mathrm{LMH}^{24}$, la más que cuestionable técnica legislativa, etc., lo que no puede admitirse es que el TS haga una interpretación tan oscura, como la que ahora nos ocupa, escudándose en esas declaraciones para evitar pronunciarse sobre la nulidad o no de esta sentencia de condena.

La Sala 5. del TS deduce de las declaraciones genéricas de injusticia e ilegitimidad que recoge la LMH la falta de vigencia en el mundo jurídico de las sentencias y condenas; incluida la que condenó a muerte a Miguel Hernández.

20 Vid. TAMARIT SUMALLA, «Transition, Historical Memory and Criminal Justice in Spain», Journal of International Justice, Volume 9, Issue 3, 2011. Vid. también en «Justicia transicional y derecho penal en España», Memoria Histórica: ¿se puede juzgar la Historia?, Madrid, Asociación de Jueces para la Democracia/Fundación Antonio Carretero, 2010, pp. 129-141.

${ }^{21}$ El texto de esta ley y su reforma está disponible en lengua inglesa, First ACt for Rectification of SED Injustice, $29^{\text {th }}$ Octover 1992, and amended the $23^{\text {rd }}$ June 1994, en KRITZ, «Germany: Compensation Acts», en vol III, Transitional Justice: Law, Ruling, and Reports (KRITZ ed.), Washington DC, United States Institte of Peace, 1995, pp. 718 y ss.

22 Antigua la República Democrática de Alemania (RDA). Vid. Art. 3 del Tratado de la reunificación de Alemania, de 5 de mayo de 1990.

${ }^{23}$ La Ley incluso, hace un listado de los delitos cuya condena obedecía normalmente a una persecución política. Véase: treasonous transmisión of information; subersive man-trade, subersive agitation; ilegal establishment of contacts; etc.

${ }^{24}$ Acaba de publicarse un pequeño libro cuya lectura es interesante para ahondar en esta línea, vid. ESCUDERO et. alii. CAMPELO, PÉREZ y SILVA, Qué hacemos por la Memoria Histórica, Madrid, Arkal, 2013. 
Sin embargo, es absolutamente absurdo además de falaz (como hace la Sala 5. ${ }^{a}$ del TS) que la sentencia que condenó a muerte a Miguel Hernández carece de vigencia jurídica, y como parece extraer del FJ 4 del ATS de 21 de febrero de 2011, que no existe ya en el mundo jurídico. Esta conclusión es errónea e irrazonable porque las sentencias, las leyes, etc. permanecen en el mundo jurídico hasta que otra norma o un órgano judicial con competencia para ello las expulse del mismo. Si la LMH u otra ley no lo ha hecho, la sentencia condenatoria de Miguel Hernández seguirá estando en el mundo jurídico hasta que un órgano judicial la expulse declarando su nulidad.

Las declaraciones de ilegitimidad e injusticia de la condena, que realizan los arts. 2 y 3 de la LMH, no significan que la sentencia de condena a Miguel Hernández carezca de validez jurídica. Esa sentencia de condena está en el mundo jurídico (y lo seguirá estando), otra cosa es que ya no tenga efectos jurídicos pero eso ocurre porque los efectos de una sentencia de condena penal se extinguen con la muerte del condenado. Esta sentencia puede que ya no tenga efectos jurídicos, pero eso no quiere decir que sea nula. Por tanto, la sentencia de condena a Miguel Hernández no sólo continúa existiendo, sino que sigue siendo válida desde el punto de vista teórico aunque ya no produzca efectos jurídicos hasta que el legislador o un tribunal declaren su nulidad.

De ahí que no sea correcta la argumentación de la Sala 5. del TS cuando señala, en el último párrafo del FJ $4 .^{\circ}$ que la sentencia «carece de toda vigencia jurídica». Esta declaración no puede hacerse mientras no se declare la nulidad de la sentencia y, a ser posible, del juicio. Y todo ello, con independencia de que los efectos de la sentencia se hayan producido. Muchas sentencias de revisión afectan a condenas ya extinguidas. Ese fue el caso, por citar un ejemplo, de la STC 123/2004, de 13 de julio, Sala 1. ${ }^{a}$ en el caso de la revisión de la sentencia condenatoria contra Francisco Granado y Joaquín Delgado, ejecutados el 17 de agosto de 1963. El Tribunal Constitucional estimó el amparo solicitado frente al auto de 3 de marzo de 1990 de la Sala 5. a del TS que denegó la autorización para interponer recurso de revisión; allí el Tribunal Constitucional declaró expresamente que el recurso de revisión «se presenta esencialmente como un imperativo de la justicia».

Por tanto, la sentencia condenatoria seguirá siendo plenamente válida en el mundo jurídico hasta que se diga expresamente lo contrario, es decir, hasta que se expulse definitivamente mediante una declaración expresa de nulidad. 


\section{EXAMEN DEL ATS, SALA 5. ${ }^{a}$ DE 21 DE FEBRERO DE 2011 DESDE EL PRISMA DE LOS DERECHOS FUNDAMENTALES}

A continuación expondremos brevemente que no es sólo lo discutible del razonamiento de la Sala 5. ${ }^{a}$ del TS, sino que además el auto de 21 de febrero de 2011 que deniega la autorización para la interposición del recurso de revisión constituye una lesión del derecho a la tutela judicial en su vertiente de acceso al proceso y a una interpretación favorable, así como del derecho a una resolución amparada en la normativa vigente.

El derecho a la tutela judicial efectiva es un derecho fundamental con un contenido amplio que no se agota en los términos del art. 24.1 CE cuando señala que todos tenemos derecho a obtener la tutela judicial efectiva de los jueces y tribunales en el ejercicio de nuestros derechos e intereses legítimos, sin que, en ningún caso, pueda producirse indefensión. El Tribunal Constitucional ha desgranado esas dimensiones concretas que conforman el contenido esencial del derecho a la tutela judicial efectiva. Por razones obvias de espacio, así como para no alejarnos del núcleo de estas reflexiones, es imposible abordar en detalle en todas esas facetas que integran el contenido esencial del derecho a la tutela judicial efectiva. Baste recordar que el derecho a la tutela judicial efectiva incluye: el derecho de acceso a la justicia; el derecho a una resolución fundada en derecho lo que incluye que esté amparada en la normativa vigente, que no sea arbitraria o irrazonable, que contenga una motivación suficiente y, que además sea congruente; el derecho a una resolución de fondo; el derecho a los recursos legalmente establecidos; el derecho a la firmeza e invariabilidad de las resoluciones judiciales firmes; el derecho a la ejecución de lo decidido; y, la interdicción de la indefensión.

A continuación, nos detendremos en las lesiones concretas que se habrían producido en este caso a propósito de la denegación de la autorización para interponer el recurso de revisión, así como por la desestimación del incidente de nulidad de actuaciones al no haber tutelado las vulneraciones denunciadas.

\subsection{El derecho a la tutela judicial efectiva en su vertiente de acceso al proceso y a una interpretación favor actionis}

El Auto de la Sala 5. ${ }^{a}$ TS de 21 de febrero de 2011 que denegó la autorización para la interposición del recurso de revisión vulneró el derecho a la tutela judicial en su vertiente de acceso al proceso y a una interpretación favorable.

El derecho de a la tutela judicial efectiva exige como prius lógico el derecho de poder acceder a la Justicia; el derecho del libre acceso a los tribunales es un requi- 
sito previo del derecho de acción. El derecho de acceso a los órganos jurisdiccionales para que se pronuncien sobre la pretensión planteada, sin exclusión de ningún conflicto jurídico; como ocurre, sin embargo, con otros métodos alternativos de resolución de conflictos (mediación, conciliación, arbitraje, etc.). Un derecho fundamental de acceso a la Justicia que se fundamenta entre otras cosas en la prohibición de la autotutela y en el monopolio estatal de la Jurisdicción.

El derecho del libre acceso a los jueces y tribunales se concreta en que sea posible sustanciar un proceso con todas las garantías; el derecho a ser parte en un procedimiento jurisdiccional, y el derecho a promover la actividad jurisdiccional que desemboque en un fallo jurisdiccional sobre las pretensiones deducidas en el procedimiento. No cabe negar arbitraria o irrazonablemente un juicio sobre fondo. Por eso, el derecho a la tutela judicial efectiva obliga también a elegir la interpretación de la ley que sea más favorable al principio pro actione o favor actionis, es decir, más favorable al ejercicio de la acción y al acceso a los Tribunales. De ahí que, el derecho a la tutela judicial efectiva sin indefensión conlleve también el derecho a que el órgano jurisdiccional haga siempre una interpretación restrictiva de las causas de inadmisión que pueden impedir la resolución de fondo. En garantía de este derecho, los jueces y tribunales tienen prohibido efectuar interpretaciones y aplicaciones de los requisitos legalmente establecidos para acceder al proceso que eliminen u obstaculicen injustificadamente, como parece haber hecho la Sala 5. ${ }^{a}$ de TS en este caso la Sala 5. el derecho a que un órgano judicial conozca y resuelva en Derecho sobre la pretensión a él sometida, debido a la vigencia del principio pro actione.

$\mathrm{Y}$ en este punto ha de tenerse en cuenta que el recurso de revisión no es un recurso sino un nuevo proceso. A pesar del debate inicial sobre este carácter, debido en parte a la errática terminología empleada por el legislador (recurso), la doctrina ${ }^{25}$ y la jurisprudencia coinciden en que el recurso de revisión representa un nuevo proceso. El Tribunal Constitucional y el Tribunal Supremo han subrayado en numerosas ocasiones ${ }^{26}$ esta naturaleza. De acuerdo con ambos, el

${ }^{25}$ Vid. en general sobre el recurso de revisión penal: MORENO CATENA, «El recurso de revisión», en El proceso penal, Valencia, Tirant lo Blanch, 2002, disponible en base de datos www. tirantonline.com, referencias: TOL100.449, TOL100.450, TOL100.451, TOL100.452, TOL100.453, TOL100.454, TOL100.455, TOL100.456. MARTÍNEZ ARRIETA, «El recurso de revisión», en Recurso de casación y de revisión penal. Control de la presunción de inocencia, Valencia, Tirant lo Blanch, 2010, pp. 321-352, disponible en base de datos www.tiratnonline.com, referencias: TOL1.947.870.

${ }^{26}$ Véase por todas, las SSTC 124/1984, Sala 2. ${ }^{a}$ de 18 de diciembre; 92/1989, Sala 2. ${ }^{a}$ de 22 de mayo; 123/2004, Sala 1. ${ }^{a}$ de 13 de julio; 59/2006, Sala 2. ${ }^{a}$ de 27 de febrero. Así como el TS desde la STS, de 26 de octubre de 1985 (RJ 1985\5064). Ya sea la Sala 5. ${ }^{a}$ TS como la Sala 2. ${ }^{a}$ TS, vid. entre otras de los últimos quince años, las SSTS 689/2011, de 16 de junio, sección 1. a ponen- 
recurso de revisión constituye un procedimiento extraordinario para rescindir sentencias firmes en aquellos supuestos en que se pone en evidencia la injusticia de una sentencia firme de condena. En un Estado social y democrático de Derecho que proclama la búsqueda de la Justicia como valor supremo no puede permitir que la inmodificabilidad de una sentencia de condena que, a posteriori, se evidencia como injusta prevalezca sobre el valor justicia. La excepcionalidad de este procedimiento pretende encontrar el necesario equilibrio entre la seguridad jurídica que reclama el respeto a la cosa juzgada y la exigencia de la justicia en que sean anuladas aquellas sentencias condenatorias de quienes resulte posteriormente acreditado que fueron indebidamente condenados.

A los efectos de la posible violación del derecho a la tutela judicial efectiva, ha de tenerse en cuenta que, la naturaleza del proceso revisión introduce en el control que corresponde al Tribunal Constitucional sobre la vulneración del derecho de acceso a los Tribunales un canon reforzado, como es el principio pro actione. Con este canon, el control constitucional de la actuación de la Sala 5. ${ }^{a}$ del TS va más allá de la simple irrazonabilidad, arbitrariedad o existencia de error (de hecho) patente en el que se quedaría si se tratase de la lesión de alguna otra de las manifestaciones del derecho a la tutela judicial efectiva, incorporando también entonces el principio pro actione.

En definitiva, la naturaleza del recurso de revisión como proceso autónomo de rescisión de sentencias firmes (vid. SSTC 70/2007, de 16 de abril, Sala 1. ${ }^{a} \mathrm{FJ}$

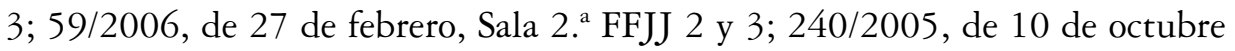
de 2005, Sala 1. ${ }^{\mathrm{a}} \mathrm{FJ} 5$ ) exige que el examen de la lesión del derecho fundamental a la tutela judicial efectiva en su vertiente de acceso al proceso supere el control de que la resolución no sea irrazonable, arbitraria o patentemente errónea, sino que además sea si es posible la más favorable al ejercicio de la acción.

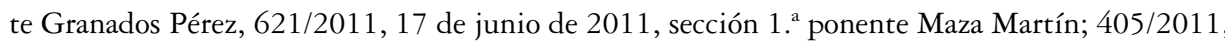
de 13 de mayo, sección 1. ${ }^{a}$ ponente Sánchez Melgar; 1/2009, de 14 de enero, STS 385/2008, de 16 de mayo, sección 1. ${ }^{a}$ Sánchez Melgar; 1495/2001, de 18 de julio, sección 1. ${ }^{a}$ ponente Granados Pérez; 520/2000, de 29 de marzo, sección 1. a ponente García-Calvo y Montiel, 176/1999, de 13 de febrero, ponente Martín Pallín, 750/1997, de 26 de mayo, sección 1. ${ }^{a}$ ponente Delgado García. La doctrina procesalista mayoritaria coincide plenamente desde hace tiempo. Vid. CORTES DOMÍNGUEZ, en Derecho Procesal Penal (MORENO CATENA, et. alii. GIMENO SENDRA, y CORTES DOMÍNGUEZ), Madrid, Colex, 1999, 3. . ed., pp. 761 y 762. También, GÓMEZ COLOMER, Derecho Jurisdiccional, Proceso Penal (MONTERO AROCA et. alii. GÓMEZ COLOMER, MONTON REDONDO, BARONA VILAR), Tomo III, Valencia, Tirant lo Blanch, 2000, 9. ${ }^{a}$ Ed., pp. 392-398. Y, como advierte, GÓMEZ COLOMER, parece que el único que mantiene su naturaleza de recurso son RIFA SOLER et. alii. VALLS GOMBAU, Derecho Procesal Penal, Madrid, Iurgium, 2000, p. 310. 
El derecho a la tutela judicial efectiva obliga a elegir la interpretación de la ley que sea más favorable al principio pro actione o favor actionis, es decir, más favorable al ejercicio de la acción. El Tribunal Constitucional ha subrayado repetidamente que el derecho a la tutela judicial efectiva sin indefensión conlleva el derecho a que el órgano jurisdiccional haga siempre una interpretación restrictiva de las causas de inadmisión que pueden impedir la resolución de fondo. Las resoluciones de la Sala $5 .^{a}$ del TS no superan este examen porque, como se ha señalado, no concurría en este caso causa de inadmisión como para inadmitir a trámite la revisión. Pero incluso aún siendo discutible tal extremo, la Sala no realizó una interpretación de aquélla conforme al principio favor actionis, es decir, de acuerdo con la alternativa más favorable al ejercicio del recurso de revisión.

El TEDH también ha señalado que las garantías procedimentales que establece el art. 6 del CEDH aseguran a cada persona el derecho a que cualquier reclamación relativa a sus derechos ${ }^{27}$ y obligaciones pueda ser presentada ante un tribunal; derecho a un tribunal entendido como el derecho a incoar un procedimiento ante los tribunales (vid. Sentencia Golder contra el Reino Unido de 21 febrero 1975). El grado de acceso determinado por la legislación nacional debe ser suficiente para garantizar a las personas el derecho a un tribunal, teniendo en cuenta el principio del Estado de Derecho en una sociedad democrática (Sentencia Ashingdane contra el Reino Unido, de 28 mayo 1985). El TEDH ha subrayado también que el CEDH garantiza no derechos teóricos o ilusorios, sino derechos prácticos y efectivos (Sentencia Airey contra Irlanda de 9 octubre 1979 y Sentencia García Manibardo contra España, de 15 febrero 2000). Por tanto, de acuerdo con el TEDH el derecho de acceso a un tribunal no se agota en el derecho a incoar un procedimiento, sino también en el derecho a obtener una «resolución» del litigio por parte de un tribunal. Sería ilusorio si el sistema legal interno de un Estado parte permitiera a una persona presentar una demanda ante un tribunal sin asegurarle que el asunto se resolviera mediante sentencia. Sería inconcebible que el art. 6.1 describiera con detalle las garantías procedimentales concedidas a los litigantes — procedimientos equitativos, públicos y rápidossin garantizar a las partes que, cuando cumplan los requisitos procesales esencia-

27 El 11 de febrero de 2007 el TEDH admitió a trámite el primer caso de revisión de una sentencia del franquismo. La demanda se presentó por los familiares de Gurnés Bou contra España. El ex alcalde de Llagostera, Eugeni Gurnés Bou, fue condenado a muerte y ejecutado por el régimen franquista el 7 de mayo de 1943. Los demandantes instaron al Tribunal a que obligase al Estado español en revisar la sentencia dictada contra Gurnés, después de que, también, dicha petición haya sido desestimada el Tribunal Supremo y el Tribunal Constitucional españoles. 
les, sus litigios sean finalmente resueltos (Sentencia Hornsby contra Grecia, ya citada).

Las resoluciones de la Sala 5. ${ }^{a}$ del TS no superan este examen sobre el respeto del derecho de acceso a los Tribunales porque, como hemos señalado, no concurría en este caso causa de inadmisión como para inadmitir a trámite la revisión. Pero incluso aún siendo discutible tal extremo, la Sala no realizó en ese primerísimo trámite una interpretación de aquélla supuesta causa de inadmisión (la falta del presupuesto objetivo) conforme al principio favor actionis, es decir, de acuerdo con la alternativa más favorable posible al ejercicio del recurso de revisión.

\subsection{El derecho a la tutela judicial efectiva en su vertiente del derecho a una resolución fundada en derecho}

Íntimamente conectada con la anterior aparece la lesión del derecho a la tutela judicial efectiva en otra dimensión, la del derecho a una resolución amparada en la normativa vigente. La interpretación seguida por la Sala 5. ${ }^{a}$ del TS en el auto de 21 de febrero de 2011, así como en su confirmación en el auto de 15 de junio de 2011 que desestimó el incidente de nulidad de actuaciones, no sólo vulneró el derecho fundamental a la tutela judicial efectiva al impedir el acceso al proceso de revisión, sino que además lo hizo siguiendo un discurso ilógico que contraviene lo dispuesto en el ordenamiento jurídico y, en especial, en la LMH.

A este respecto cabe decir también que el contenido esencial del derecho a la tutela judicial efectiva incluye el derecho a la obtención de una respuesta de la Sala amparada en la normativa vigente y, no sólo eso, sino que además sea motivada, congruente y no arbitraria o irrazonable. Las cláusulas amparada en la normativa vigente y no arbitraria o irrazonable se coligen inequívocamente de los apartados 1 y 3 del art. 9 CE que disponen el sometimiento de todos los sujetos y poderes públicos a la $\mathrm{CE}$ y al resto del ordenamiento jurídico, y prohíben expresamente la arbitrariedad de los poderes públicos.

En un epígrafe previo se ha explicado que la deducción que la Sala 5. ${ }^{a}$ del TS extrae de las declaraciones de ilegitimidad e injusticia de los arts. 2 y 3 de la LMH, sobre que la sentencia de condena cuya nulidad se solicitaba no está en el mundo jurídico y carece de vigente, no parece estrictamente posible si nos atenemos a la ley. No creemos que sea preciso volver a insistir en los argumentos.

Sin embargo, si es preciso subrayar ahora que además la deducción que efectúa la Sala 5. ${ }^{a}$ del TS infringe singularmente lo dispuesto en el art. 4.1 y en la disposición adicional 2. ${ }^{a}$ de la LMH 
El art. 4 de la LMH reconoce expresamente que el derecho a obtener una declaración de reparación y reconocimiento personal, de quienes durante la Guerra Civil y la Dictadura padecieron los efectos de las resoluciones a que se refieren los arts. 2 y 3 de la LMH, es plenamente compatible con los demás derechos y medidas reparadoras reconocidas en normas anteriores, así como con el ejercicio de las acciones a que bubiere lugar ante los tribunales de justicia.

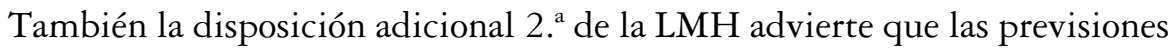
contenidas en la LMH son compatibles con el ejercicio de las acciones y el acceso a los procedimientos judiciales ordinarios y extraordinarios establecidos en las leyes o en los tratados y convenios internacionales suscritos por España.

$\mathrm{Y}$ entre esas acciones compatibles ha de entenderse incluido el proceso de revisión ante el TS si concurre alguno de los motivos excepcionales previstos en la LPM o en la LECrim.

Una compatibilidad que la Sala 5. a del TS no parece compartir y, que desde luego a pesar de la garantía constitucional de sumisión al imperio de la ley a la que se debe (art. 117.1 CE), no respeta. Según su iter discursivo la ilegitimidad del Consejo de Guerra que condenó a $M H$, el carácter radicalmente injusto de la sentencia de condena de $M H$, y la ilegitimidad de la condena a muerte a $M H$ no es compatible con el ejercicio de acciones previstas en nuestro ordenamiento jurídico ante los tribunales de justicia; al menos no de la acción de revisión.

Y en este punto es preciso subrayar la importancia de la lesión del derecho a la tutela judicial efectiva que comporta la interpretación de la Sala 5. a del TS. Quizá la Sala 5. ${ }^{a}$ no visualizase inicialmente las graves consecuencias de esta interpretación porque cuando deniega la autorización para la interposición de la revisión basándose en la supuesta falta del presupuesto objetivo porque la sentencia cuya revisión se pide no está en el mundo jurídico porque carece de vigencia desde que la LMH declarase la injusticia e ilegitimidad de las condenas.

$\mathrm{Y}$ es que, no debe pasarse por alto que el argumento de la Sala 5. ${ }^{\text {a }}$ del TS cierra a la postre, como trató de explicar el voto particular, las puertas a la acción de revisión no sólo a este caso (el de la sentencia de condena a muerte de Miguel Hernández), sino a cualquiera de las sentencias de condena recogidas en los arts. 2 y 3 de la LMH. Por eso, la vulneración del derecho a la tutela judicial efectiva que en este punto se produce es singularmente grave y deplorable.

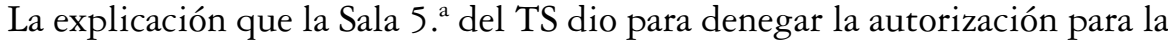
interposición de la revisión (el hecho de que supuestamente faltase el presupuesto objetivo de la revisión porque la LMH haya declarado que las condenas dictadas en esos casos son ilegítimas e injustas) no sólo conlleva que no ha lugar a la interposición de la revisión en este caso, sino que a la postre determina también que en general la revisión no procede frente a las sentencias de condena a 


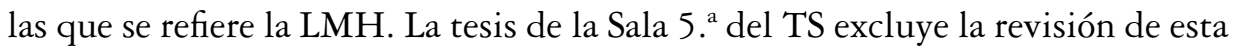
sentencia, pero también la de cualquiera de aquellas sentencias injustas e ilegítimas a las que se refieren los arts. 2 y 3 de la LMH. La tesis de la supuesta falta del presupuesto objetivo del recurso de revisión por las declaraciones que efectúa la $\mathrm{LMH}$, restringe abruptamente que cualquiera de las sentencias a que se refieren el objeto de la $\mathrm{LMH}$ sean revisadas en un futuro ${ }^{28}$.

De hecho, quizá consciente de los peligrosos efectos de su razonamiento, la Sala 5. ${ }^{a}$ incurre en varias contradicciones in fine en el auto de 21 de febrero de 2011; y es que paradójicamente utiliza argumentos incompatibles con la base de su argumento. Así, la Sala 5. ${ }^{a}$ del TS parece querer dejar in fine la puerta abierta a la nulidad de la sentencia aunque no sea a través del recurso de revisión cuando señala que: anticipamos que no es posible efectuar la declaración que se nos pide porque, sin perjuicio de que la Sentencia podría ser nula sobre la base del contenido de la Ley 52/2007, un pronunciamiento de esta clase no sería congruente con el procedimiento basta abora seguido (...) (ATS, Sala 5. ${ }^{\mathrm{a}}$ de 21 de febrero de 2011, núm. rec. 54/2010, FJ 5). ¿Podría entonces declararse la nulidad de la sentencia? Si el legislador no ha declarado la nulidad y si la revisión no es el procedimiento congruente para obtener ese pronunciamiento de nulidad ¿qué procedimiento sería entonces el apropiado?

\subsection{El derecho a la presunción de inocencia}

La interpretación de la Sala 5. ${ }^{a}$ del TS, al ser contraria al derecho a la tutela judicial efectiva en el sentido descrito en los dos puntos anteriores, termina vulnerando asimismo el derecho a la presunción de inocencia de quien se ha visto favorecido por una declaración legal de injusticia y de ilegitimidad de la sentencia y condena (la sentencia del 18 de enero de 1940); así como del Tribunal que la dictó (el Consejo de Guerra núm. 5 de Madrid).

28 Advertir el disparate a que ello conduciría exige ilustrar el resultado con un ejemplo de laboratorio terrible. Imaginemos por un momento que en aquella fecha un Consejo de Guerra hubiera condenado a muerte a $\mathrm{A}$ por el homicidio de $\mathrm{B}$ que era una persona cercana al régimen dictatorial. Y, que B supuestamente fallecida aparece o que, incluso, se acredita que vivía después de la sentencia condenatoria, aunque en la actualidad hubiese ya fallecido. Pues bien, siguiendo el razonamiento de la Sala 5. ${ }^{a}$ del TS, ni A ni su familia podrían solicitar la revisión porque falta uno de los presupuestos de la revisión. Y es que la sentencia de condena ya no existe en el mundo jurídico, carece de vigencia jurídica, desde que la LMH declarase con carácter general que las condenas fueron injustas y los tribunales ilegítimos. Parece obvio el dislate que ello significaría y la vulneración directa del derecho a la tutela judicial efectiva en su vertiente de acceso al proceso que una interpretación de ese tipo significaría. 
La finalidad del recurso de revisión es que el valor Justicia (art. 1.1 CE) prevalezca sobre la seguridad jurídica en aquellos procesos en que resulten gravemente afectados los derechos del condenado. Algo que sin lugar a dudas ocurre cuando la sentencia es injusta; y, en este caso esa injusticia ha sido declarada precisamente por la $\mathrm{LMH}$.

No debemos olvidar que la injusticia de la sentencia es el vicio que se trata erradicar con la revisión y la pieza angular que fundamenta un proceso de estas características. Sirva por todas, la STS 176/1999, Sala 2. a de 20 de febrero, a tenor de la cual en la revisión «nos encontramos ante un cauce procesal que trata de conciliar el principio de la seguridad jurídica, que conviene e interesa a todos los sistemas jurídicos para garantizar la estabilidad de las resoluciones judiciales, con la búsqueda de la justicia que se ha convertido, además, en uno de los valores superiores del ordenamiento jurídico. Es evidente que el orden público, en su verdadero sentido constitucional, no puede soportar indiferentemente la ruptura de la armonía jurídica que supone la pervivencia de sentencias radicalmente injustas» (la cursiva es nuestra).

Si la sentencia de condena a Miguel Hernández es radicalmente injusta (además de ilegítima), y así lo ha declarado expresamente la LMH, es inadmisible mantenerla; y eso, aunque la responsabilidad penal se haya extinguido por su muerte. En el mundo jurídico no debería seguir considerándose como culpable de un hecho a quien se condenó con una sentencia injusta e ilegítima; pero estrictamente en el mundo jurídico seguirá siendo así mientras no haya una declaración expresa de nulidad.

La nulidad de una sentencia sólo puede declararse bien por el legislador o bien por un órgano judicial. La LMH no contiene una declaración expresa y general de nulidad de las sentencias de la represión franquista. La LMH no alcanza a declarar de forma general la nulidad radical de las sentencias y condenas a las que se refiere, como la de $\mathrm{MH}$, pero sí recoge los presupuestos necesa$\operatorname{rios}^{29}$ para que los órganos jurisdiccionales competentes así lo declaren. A diferencia de la ley alemana, la LMH no prevé un procedimiento expreso para conseguir esa declaración de nulidad de las sentencias afectadas en estos supuesto. Por eso, en este y otros casos se ha utilizado la única vía al alcance de las partes que era el proceso de revisión de sentencia.

${ }^{29}$ ESCUDERO ALDAY, «Los tribunales españoles ante la Memoria Histórica: el caso de Miguel Hernández», en Hispania Nova. Revista de Historia Contemporánea, núm. 11, 2013, disponible en http://hispanianova.rediris.es; en concreto pp. 4-5. El mismo autor, «La declaración de ilegitimidad de los tribunales franquistas: una vía para la nulidad de sus sentencias», en Derecho y memoria histórica (MARTÍN PALLÍN et. al. ESCUDERO eds.), Madrid, Trotta, 2007, pp. 222-229. 


\section{EL FONDO DEL RECURSO DE REVISIÓN Y LOS HECHOS Y PRUEBAS ALEGADOS COMO NUEVOS AL OBJETO DE LA REVISIÓN DE LA CONDENA FIRME}

En este epígrafe reflexionaremos brevemente sobre los tres hechos nuevos alegados por la nieta de Miguel Hernández para solicitar la autorización para la interposición del recurso de revisión. 1. Pruebas y diligencias practicadas en un proceso penal seguido ante el Tribunal Militar de Orihuela que se conocieron con posterioridad. 2. La Ley de Memoria Histórica ${ }^{30}$; y 3. La declaración de reparación y reconocimiento personal, regulada en el art. 4 de la $\mathrm{LMH}$, concedida a favor de Miguel Hernández.

La Sala 5. ' del TS ignoró y omitió pronunciarse sobre cualquiera de estos tres hechos nuevos que, según la solicitante de la revisión, evidenciarían la injusticia de la sentencia de condena escudándose, como se ha explicado, en la supuesta falta de presupuesto objetivo de la revisión.

Sin embargo, en este trabajo parece oportuno referirse siquiera sea brevemente a esos hechos nuevos. En especial en lo que al segundo y tercer motivo se refiere porque la LECrim (art. 954) y la LPM (art. 328) no han previsto expresamente tales supuestos como motivo de revisión.

El legislador no ha previsto estrictamente como motivo ${ }^{31}$ para la interposición del recurso de revisión penal que una persona haya sido condenada por una sentencia que más tarde se haya declarado legalmente como injusta (radicalmente injusta para ser exactos) e ilegítima (por vicios de fondo y forma); tampoco que ilegítimo fuera el Tribunal/Consejo que dictó la sentencia; ni que las declaraciones anteriores, en lugar de hacerse genéricamente por ley, las haya hecho el Estado, a través del Ministerio de Justicia.

Nadie pone en duda que el necesario equilibrio entre el valor Justicia y el principio de seguridad jurídica exige una interpretación taxativa de los motivos del recurso de revisión.

No obstante, en el concepto de hecho nuevo debería incluirse también aquellos elementos que contribuyan a acabar con tal injusta situación; es decir, no sólo nuevos datos, aspectos o elementos de prueba (como testimonios, documentos o

30 A la Ley 52/2007, de 26 de diciembre, se le ha denominado generalmente con el nombre de Ley de Memoria Histórica, pero su título completo es el de Ley por la que se reconocen y amplían derechos y se establecen medidas en favor de quienes padecieron persecución o violencia durante la guerra civil y la dictadura.

31 Vid. en este sentido la opción apuntada por ARAGÜENA, «La ley de memoria histórica y sus limitaciones: una visión desde la óptica del derecho procesal», en Justicia de transición, justicia penal internacional y justicia universal (TAMARIT SUMALLA ed.), Barcelona, Atelier, 2010, p. 130. 
informes), sino todo aquello que contribuya a anular una sentencia injusta porque una sentencia injusta vulnera, en nuestro sistema constitucional, las más elementales exigencias del debido proceso y de la tutela judicial efectiva.

Ha de tenerse presente, como ya se ha dicho anteriormente, que la injusticia de una sentencia es precisamente, según jurisprudencia y doctrina constitucionales constantes ${ }^{32}$, la pieza angular que fundamenta el recurso de revisión; en otras palabras la finalidad última y la justificación que late detrás de un proceso tan extraordinario como la revisión.

Por eso, en la práctica no debería mantenerse una interpretación tan rigorista como para negar el acceso a la revisión de una sentencia que legalmente ya ha merecido el adjetivo de injusta (véase la LMH) por no encuadrarse estrictamente en el concepto de hecho nuevo de los arts. 954.4 de la LECrim o 328.6. ${ }^{\circ}$ de la LPM. De ahí que tanto la declaración de injusticia e ilegitimidad genéricas de la $\mathrm{LMH}^{33}$, como la declaración singular de reparación y reconocimiento personal alegados como hechos nuevos merecerían incluirse en el concepto de «hecho nuevo».

La necesidad de una interpretación flexible de lo que es un becho o una prueba nueva a los efectos de la revisión de una condena más allá de los expresamente previstos hasta ahora no es algo inverosímil jurisdiccionalmente, ni siquiera incluso a los ojos del legislador.

Así, el Tribunal Constitucional y también el Tribunal Supremo ${ }^{34}$ han ido admitiendo progresivamente una interpretación más flexible de esos hechos o pruebas nuevas que permiten abrir la puerta a la revisión de una sentencia de condena, sobrepasando así los angostos límites de una interpretación literal; y, ello sin perjuicio de la decisión que finalmente recayese en el juicio rescisorio. Por ejemplo, se han admitido como «hecho nuevo» a los efectos de la posible revisión de la sentencia desde una sentencia del Tribunal Constitucional (STC 150/1997, Sala 2. ${ }^{a}$ de 29 de septiembre) a un Dictamen del Comité de Derechos Humanos de Naciones Unidas (ATC 260/2000, sección 4. a de 13 de

32 Nos remitimos a las notas al pie 25 y 26.

33 VICENTE BALLESTEROS, «La Ley de Memoria Histórica como motivo de revisión penal», Jueces para la democracia, núm. 74, 2012, pp. 70-82.

34 Véase en especial la interpretación flexible efectuada por la Sala 2. ${ }^{a}$ del TS, más allá de los casos previstos en el art. 954 LECrim. Vid. SSTS, 1494/1998, Sala 2. a de 30 de noviembre de 1998 (Roj: STS 7152/1998, rec. 2980/1996) a propósito del non bis in idem; 296/2004, Sala 2. a de 10 de marzo de 2004 (Roj: STS 1642/2004, rec. 51/2003) sobre exclusión de la agravante de reincidencia aplicada con base en el error de la certificación de antecedentes penales. 
noviembre ${ }^{35}$ ). De hecho, mucho antes, la STC 245/1991, Pleno, de 16 de diciembre, estimó un recurso de amparo al considerar que el TS había vulnerado, en el trámite previo del recurso de revisión, el derecho a la tutela judicial efectiva al no otorgar consecuencia alguna a la declaración de violación del art. 6.1 CEDH que había hecho el Tribunal de Estrasburgo, y consideró que aquella sentencia del sistema europeo de protección de derechos humanos era un becho nuevo.

Una interpretación por tanto más amplia que, también, podría haberse hecho en este caso de haberse entrado a valorar los motivos del recurso de revisión solicitado, en aras a la solución justa, equitativa, humana y constitucional. Nada debería oponerse en la actualidad a que la Constitución en general y los valores y derechos fundamentales allí proclamados, y en particular las declaraciones expresas de la LMH sobre injusticia e ilegitimidad de las sentencias de condena (arts. 2 y 3 de la LMH) y/o las declaraciones de reconocimiento personal del art. 4 de la LMH puedan alcanzar el rango de hecho nuevo a los efectos de la revisión. Máxime cuando no existen otros mecanismos para hacer valer los derechos de los condenados en aquellas sentencias.

De hecho, el legislador también parece haberse hecho eco del déficit de la regulación actual de los motivos que permitirían abrir el juicio de revisión. Por eso, los dos únicos Anteproyectos de una nueva LECrim publicados hasta la fecha establecen más supuestos de los que ahora recoge el art. 954 de la LECrim, o recogen los ya clásicos con otros términos, lo que permite una interpretación más amplia como ocurre concretamente en el caso de los hechos y pruebas nuevas.

En primer lugar, el Anteproyecto de LECrim publicado el 31 julio de 2011 recogía, como subrayaba la Exposición de Motivos, nuevos motivos para la interposición del recurso de revisión en los arts. 660 y 670. Así, se establecía que podrá promoverse la revisión de las sentencias, a pesar de su firmeza, en los casos siguientes:

a) Cuando hayan sido condenadas dos o más personas en virtud de sentencias contradictorias por un mismo hecho que no haya podido ser cometido más que por una sola;

35 Aunque este auto inadmite el recurso de amparo, en lo que aquí interesa, el Tribunal Constitucional precisamente defendía un criterio extensivo en la interpretación del concepto de hecho nuevo del art. 954.4 LECrim. El Tribunal Constitucional inadmitió la demanda de amparo porque el recurrente debía haber acudido con el dictamen del Comité de Derechos Humanos de la ONU al Tribunal Supremo en lugar de en amparo al Tribunal Constitucional porque «el Dictamen de la Comisión puede ser tenido por un hecho nuevo a los efectos de lo dispuesto en el art. 954.4 LECrim, en relación con lo declarado, mutatis mutandi, en la STC150/1997, Sala 2. ${ }^{a}$ de 29 de septiembre». 
b) Cuando haya sido condenada una persona en sentencia cuyo fundamento fuera: un documento o testimonio declarados después falsos por sentencia firme en causa criminal, la confesión del reo arrancada por violencia o coacción o cualquier otro hecho punible ejecutado por un tercero, siempre que tales extremos resulten también declarados por sentencia firme en procedimiento seguido al efecto. A estos fines podrán practicarse cuantas pruebas se consideren necesarias para el esclarecimiento de los hechos controvertidos en el procedimiento, anticipándose aquéllas que por circunstancias especiales pudieran luego dificultar y hasta hacer imposible la sentencia firme base de la revisión;

c) Cuando haya sido condenada una persona en sentencia dictada por el Tribunal y alguno de sus miembros fuere condenado por prevaricación cometida en aquella sentencia o cuando en la tramitación de la causa se hubiere prevaricado en resolución o trámite esencial de influencia notoria a los efectos del fallo.

d) Cuando después de la sentencia sobrevenga el conocimiento de nuevos hechos o de nuevos elementos de prueba, que de haber sido conocidos hubieran determinado la absolución.

e) Cuando el TEDH hubiese declarado la violación de alguno de los derechos reconocidos en el CEDH, siempre que dicha vulneración haya sido relevante o determinante de la condena.

f) Cuando sobre los mismos hechos y acusados hayan recaído dos sentencias firmes y dispares dictadas por la misma o por distintas jurisdicciones; en principio, parece que el problema se daría en el ámbito contencioso administrativo.

g) Y, quizá más importante en lo que al objeto de estas líneas se refiere el anteproyecto preveía también en el art. 670 como nuevo supuesto de revisión de las sentencias firmes, un cambio legislativo. Con todo es cierto, que ese cambio legislativo no es como el que aquí se ha defendido el de la declaración de injusticia e ilegitimidad efectuado por la LMH, sino la revisión de la sentencia de condena por aplicación del principio de retroactividad de la disposición penal más favorable.

Por otro lado, el 24 de febrero de 2013, el Ministerio de Justicia dio a conocer el texto de la propuesta de nuevo Código Procesal Penal que el tomará como punto de partida para ultimar un nuevo Anteproyecto y remitirlo para su discusión y tramitación a las Cortes Generales. En lo que aquí importa, el proceso de revisión de sentencias firmes, el art. 623 propone como motivos para solicitar la revisión:

a) Cuando haya sido condenada una persona en sentencia que haya valorado como prueba un documento o testimonio declarados después falsos, la confesión del reo arrancada por violencia o coacción o cualquier otro hecho punible ejecutado por un tercero, siempre que tales extremos resulten declarados por sentencia firme en procedimiento penal seguido al efecto. 
Motivo similar al recogido en la actualidad en el art. 954.3 LECrim, pero proponiendo ahora añadir que «No será exigible la sentencia condenatoria cuando el proceso penal iniciado a tal fin sea archivado por prescripción, rebeldía, fallecimiento del encausado u otra causa que no suponga una valoración de fondo».

b) Cuando haya recaído sentencia penal firme condenando por el delito de prevaricación a alguno de los Magistrados o Jueces intervinientes en virtud de alguna resolución recaída en el proceso en el que recayera la sentencia cuya revisión se pretende, sin la que pueda presumirse que el fallo hubiera sido distinto.

c) Cuando sobre el mismo hecho y encausado hayan recaído dos sentencias firmes.

d) Cuando después de la sentencia sobrevenga el conocimiento de hechos o elementos de prueba, que, de haber sido aportados, bubieran podido determinar la absolución o una condena menos grave ${ }^{36}$.

Es importante subrayar dos matices importantes que incluye el texto propuesto en la redacción de este motivo clásico y que en principio marcan o podrían marcar singulares diferencias con el vigente art. 954.4. ${ }^{\circ}$ LECrim.

Por un lado, el texto propuesto afortunadamente deja de referirse a hechos o pruebas nuevas que «evidencien» la inocencia del condenado y se refiere «a hechos o pruebas que hubieran podido determinar»; y, por otro lado, omite cualquier referencia a la inocencia del condenado y se refiere a hechos nuevos o pruebas que bubieran podido determinar la absolución o a una condena menos grave.

e) Cuando el TEDH bubiese declarado la violación de alguno de los derechos reconocidos en el CEDH, siempre que dicha vulneración haya sido relevante o determinante de la condena.

\section{LA TRASCENDENCIA CONSTITUCIONAL DE LA DEMANDA DE AMPARO}

Desgraciadamente, la sección $4 .^{a}$ del Tribunal Constitucional inadmitió mediante providencia ${ }^{37}$ de 17 de septiembre de 2012 la demanda de amparo

36 Previamente en general no se admitían los casos en que se admitía el proceso de revisión cuando los hechos alegados sólo suponían una pena de menor gravedad. Aunque, como ya hemos visto, había jurisprudencia contradictoria en este sentido. Vid SSTS, Sala 2. ${ }^{a}$ de 6 de mayo de 1975 (RJ 1975 2078); de 25 de junio de 1984 (RJ 1984 3677); de 25 de febrero de 1985 (RJ 1985\1540).

${ }^{37}$ Las providencias de inadmisión de los recursos de amparo no se publican, siendo éste un problema grave del nuevo sistema de admisión del amparo constitucional que denunciamos en otro momento junto a otros autores. Vid. OUBIÑA BARBOLLA, «Encuesta», La reforma de la Justicia Constitucional, Cizur Menor, Thomson-Aranzadi/ CEJ, 2006, p. 109; también en, El Tribunal Constitucional: pasado, presente y futuro, Valencia, Tirant lo Blanch, 2012, p. 433. Por eso, coincidimos con GARCÍA TORRES en que es complicado desalentar a los recurrentes de la interposición si las inadmisiones que deben servir de desincentivo no se publican, cfr. «Encuesta», 
presentada por la nieta de Miguel Hernández frente a las lesiones de derechos

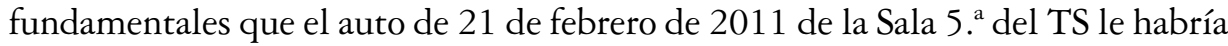
causado al denegar la autorización para interponer la revisión; unas lesiones cuya tutela tampoco habría atendido después de haber intentado el incidente de nulidad de actuaciones. La sección 4 . $^{\mathrm{a}}$ del Tribunal Constitucional aduce en apenas cuatro líneas «la manifiesta inexistencia de violación de un derecho fundamental tutelable en amparo, violación que, de acuerdo con el art. 44.1 LOTC, es condición para que este Tribunal pueda ejercer dicha tutela».

La reforma del art. 50 de la LOTC, operada por la LO 6/2007, 24 de mayo, invirtió la perspectiva de la primera fase del proceso de amparo constitucional; la decisión de inadmisión se sustituyó por una decisión expresa de admisión. El antiguo juicio de admisibilidad basado en comprobar la existencia de una o varias causas de inadmisión se ha convertido en verificar si el contenido del recurso reúne especial trascendencia constitucional que justifique una decisión sobre el fondo por parte del Tribunal Constitucional. Por supuesto, el recurso de amparo debe seguir reuniendo los requisitos de los arts. 41-46 y 49 LOTC.

De la escueta providencia lo único que puede extraerse es que según la sección 4. ${ }^{a}$ del Tribunal Constitucional en el caso expuesto en la demanda no existe violación de un derecho fundamental tutelable en amparo.

Sin embargo, creíamos y creemos que el recurso de amparo debía haberse admitido y estimado porque el auto de 21 de febrero de 2011 vulnera, como se ha intentado exponer anteriormente, el derecho a la tutela judicial efectiva en su vertiente de acceso al proceso (art. 24.1 CE), el derecho a la tutela judicial efectiva en lo que se refiere al derecho a una resolución amparada en la normativa vigente, no arbitraría, irracional o patentemente errónea (art. 24.1 CE), así como indirectamente el derecho a la presunción de inocencia (art. 24.2 CE). Sin embargo, éramos realistas y por eso, habíamos imaginado otras posibilidades.

Intentaremos explicar a continuación la trascendencia constitucional que reunía la demanda de amparo presentada por la nieta de Miguel Hernández para haber superado el trámite de admisión del proceso de amparo y, resolverse por

La reforma de la Justicia..., ob. cit., p. 103. Además, la publicación podría servir para minimizar el problema de que la falta de motivación dificulte una doctrina sobre la admisibilidad CRUZ VILLALÓN, «La réforme de la justice constitutionnelle espagnole», cit., pp. 727-728. Algo similar concluye García Roca, «Encuesta sobre la reforma de la LOTC», Teoría y realidad constitucional, núm. 4, 1999, cit., p. 42. En cambio GUI MORI, «La modificación de la Ley Orgánica del Tribunal Constitucional. Profunda reforma del recurso de amparo y de la nulidad de actuaciones», Diario La Ley, núm. 6791, 2 octubre, Año XXVIII, ref. D-207, la Ley 5366/2007, p. 7 consideró suficiente que la reforma haya previsto la publicación de los autos, pero no advierte que, a salvo los que resuelvan las súplicas, en la admisión todas las resoluciones son ahora providencias. 
tanto sobre el fondo; además de, por supuesto, cumplir también los requisitos clásicos de los arts. 41-46 y 49 LOTC. Justificar la trascendencia constitucional de la lesión es algo más y distinto de la obligación de motivar la existencia de la vulneración del derecho fundamental por la lesión impugnada.

La LOTC recoge tres parámetros para apreciar si el recurrente ha justificado en su demanda la «especial trascendencia constitucional» de su amparo. Las pautas son descritas de forma finalista; se hará atendiendo a la importancia para: a) La interpretación de la CE; b) La aplicación o la general eficacia de la CE; y, c) La determinación y alcance de los derechos fundamentales [art. 50.1 b)]. Basta con que la relevancia constitucional del amparo haya quedado justificada con uno de ellos ${ }^{38}$ para que el recurso sea admitido. Estrictamente cualquiera de las tres se resume en una idea: la admisión sólo está reservada a la demanda de amparo que plantee un problema constitucional de cierta entidad.

Durante los dos primeros años de vigencia de reforma (2007-2009) poco o nada se supo de lo que el Tribunal Constitucional entendía por esa especial trascendencia constitucional. La STC 155/2009, de 25 de junio marcaría un antes y un después en esta nebulosa ${ }^{39}$. El Pleno del Tribunal Constitucional explicó a grandes rasgos, en su FJ 2, qué supuestos tienen esa singular trascendencia constitucional que merecen una decisión de fondo del Tribunal Constitucional.

Antes de continuar, es preciso subrayar que la interpretación que se ha dado de la especial trascendencia constitucional no es definitiva, ni puede tomarse como un numerus clausus. Y, no lo decimos nosotros sino el Tribunal Constitucional el significado de la trascendencia constitucional es esencialmente dinámico, es decir, que se va a ir perfilando en el futuro y que se depurará y adaptará a los tiempos.

Sea como fuere, según el Tribunal Constitucional hoy la lesión de un derecho fundamental o libertad pública tiene, o puede tener, esa especial trascendencia constitucional cuando: a) No existe doctrina constitucional; b) Dé la oportunidad al Tribunal Constitucional para aclarar o cambiar su doctrina, como consecuencia de un proceso de reflexión interna, o por el surgimiento de nuevas realidades sociales o de cambios normativos relevantes para la configuración del contenido de ese derecho o libertad fundamental, o de un cambio en la doctrina de otros órganos

${ }^{38}$ Los tres criterios son fórmulas alternativas que desarrollan el mismo concepto objetivo; por eso un sector de la doctrina sugirió su simplificación en un sólo enunciado: v.gr. «la proyección o relevancia general que ofrezca el caso sobre el alcance y configuración de los derechos o libertades en juego». Sin embargo, se trata sólo de una analogía parcial, porque no todo lo que es trascendente para la interpretación de la CE lo es para la determinación y alcance de los derechos fundamentales, aunque si a la inversa. Por eso, nosotros aplaudimos que no se hayan refundido.

39 Hasta entonces el Tribunal Constitucional sólo había identificado esporádicamente algunos supuestos, véase por ejemplo la STC 70/2009, Sala 1. ${ }^{a}$ de 23 de marzo, FJ 1. 
jurisdiccionales supranacionales; c) Haya sido causada inmediatamente por una ley u otra disposición de carácter general; d) También cuando tenga origen en la interpretación jurisprudencial de la ley; e) Provenga del incumplimiento general y reiterado de la doctrina constitucional por parte de la jurisdicción ordinaria, o existan resoluciones judiciales contradictorias sobre el derecho fundamental, ya sea interpretando de manera distinta la doctrina constitucional, ya sea aplicándola en unos casos y desconociéndola en otros; f) También cuando tenga origen en la negativa manifiesta de un órgano judicial del deber de acatamiento de la doctrina constitucional (art. 5 LOPJ); g) Cuando el asunto suscitado trascienda del caso concreto porque plantea una cuestión jurídica de relevante repercusión social o económica, o tenga unas consecuencias políticas generales que podrían concurrir, sobre todo, aunque no exclusivamente en determinados amparos electorales o parlamentarios.

A primera vista, la interpretación que el Tribunal Constitucional ha atribuido a la nueva cláusula de la especial trascendencia constitucional parece sólido y completo. Sin embargo, se ha criticado también ${ }^{40}$ que por la dicción y las expresiones utilizadas, parece que todas las claves que el Tribunal Constitucional señaló en esa sentencia, salvo la primera, están enfocadas sólo hacía la estimación del amparo; y, ante esa posibilidad, hay que preguntarse si acaso las decisiones de fondo desestimatorias no son a veces también muy importantes para la doctrina, la jurisdicción ordinaria y, en general para todos (poderes públicos y particulares).

Dejando a un lado esa cuestión, la familia de Miguel Hernández justificó en su demanda la trascendencia constitucional del recurso siguiendo algunas de las directrices dadas por el Tribunal Constitucional. Una trascendencia constitucional que no se agota en este caso singular, sino que es extensible (o lo sería) a la trascendencia constitucional de otros casos en que la Sala $5 .{ }^{a}$ del TS deniegue la autorización para la interposición del recurso de revisión de sentencias similares utilizando el argumento de que esas sentencias de condena firme, cuya nulidad se pide, ya no existen desde que la LMH declarase que fueron radicalmente injustas e ilegítimas por vicios de fondo y forma, y carecen en la actualidad por tanto de cualquier vigencia jurídica. Explicaremos a continuación una por una la trascendencia constitucional de estos casos siguiendo los parámetros atendiendo a los parámetros dados por el Tribunal Constitucional en la STC 155/2009, de 25 de junio.

- Se trata de una cuestión novedosa o de un problema o aspecto diferente sobre el derecho fundamental a la tutela judicial efectiva en su vertiente de acceso al proceso sobre el que no existe doctrina constitucional [vid. criterio a) de la STC 155/2009, FJ 2].

${ }^{40}$ OUBIÑA BARBOLLA, El Tribunal Constitucional: pasado, presente y futuro, Valencia, Tirant lo Blanch, 2012, pp. 499-500. 
En su base el caso de Miguel Hernández encierra una cuestión esencial como es si la solicitud de la revisión de una condena puede fundarse en una ley, concretamente la $\mathrm{LMH}$, que ha declarado con carácter general el carácter injusto de las condenas y la ilegitimidad de los Tribunales que la impusieron; lo que en el caso de Miguel Hernández significa, mutatis mutandis, que su condena a muerte fue injusta y que el Tribunal que la impuso era ilegítimo.

En apoyo de esta tesis, sin ir más lejos, encontraríamos la falta de unanimidad de la Sala 5. ${ }^{a}$ del TS que dio origen a que uno de los Magistrados (D. Javier Juliani) formulase un voto particular. Podríamos incluso traer a colación a este respecto algo interesante; y es que, entre las diversas alternativas que durante muchos años se plantearon sobre la reforma del amparo constitucional hubo una en la que un voto particular discrepante en instancias previas era considerado precisamente uno de los indicios de la trascendencia constitucional de la lesión como para ser admitido a trámite. En particular, cuando se hablót ${ }^{41}$ de la posibilidad de crear una Sala constitucional o de amparo en el TS. Ahora bien, esta posible Sala de amparo se dibujaba con diferentes matices porque en sí misma una Sala de amparo en el TS no tendría por qué frenar la demanda de amparo ante el TC, sino que podía convertirse simplemente en un paso previo. De ahí, que se plantease la posibilidad de articular a continuación una nueva causa de inadmisión en el proceso de amparo constitucional pivotada en dos elementos; a saber: uno, el voto particular ${ }^{42}$ de un Magistrado en la vía jurisdiccional previa o en el agotamiento de los recursos procedentes (incluido el paso por la Sala de amparo en el TS); y otro, el informe favorable del Ministerio Fiscal en el amparo constitucional.

41 FERNÁNDEZ FARRERES reconoce que la idea «no es absolutamente original», cfr. El recurso de amparo constitucional: una propuesta de reforma, Documento de trabajo 58/2004, Madrid, Fundación Alternativas, pág. 7. En nuestra opinión los antecedentes estaban en el prólogo de TOMÁS Y VALIENTE, precisamente a una obra de Fernández Farreres, en el que curiosamente criticaba la idea de crear una Sala de amparo en el TS: si «se limitara el legislador a crear una instancia obligada ante el TS para agotar la vía ordinaria en los casos de reclamaciones contra violaciones judiciales de los derechos del art. $24 \mathrm{CE}$, sin llevar a cabo al mismo tiempo una reducción en la legitimación para recurrir frente a la última resolución judicial ante el Tribunal Constitucional por vía de amparo, lo único que se habría dilatado es el momento en que se interpondría, sin reducir con ello su número; (...) corriendo el riesgo (...) de incumplir el mandato constitucional de la sumariedad, que, entre otras cosas significa rapidez. Ahora bien: ¿está el legislador dispuesto a restringir la legitimación de los recurrentes, atribuyéndola sólo al Ministerio Fiscal en esa fase final del amparo judicial?». Sobre esa posibilidad de la legitimación en exclusiva al Ministerio Fiscal, vid. ESPÍN TEMPLADO, «Los recursos constitucionales», cit., pp. 480-482.

${ }^{42}$ El componente del voto particular, lo había traído al debate SORIANO GARCÍA, «La guerra de los dos Tribunales: una propuesta de paz (la necesaria reforma del recurso de amparo)», REDA-Civitas, núm. 123, 2004, pp. 467-468. 
La reforma del recurso de amparo transcurrió, como ya sabemos, por otro camino, pero en su momento la existencia de un voto particular previo fue valorada muy positivamente como un posible argumento para la admisión a trámite de la demanda de amparo. Sea como fuera y, dejando a un lado ya este pequeño matiz, nunca fuimos nosotros entusiastas de aquella propuesta pues adolecía de otros riesgos ${ }^{43}$.

Ahora bien, la relevancia constitucional del caso que nos ocupa también podría haberse explicado a través de otros de los criterios apuntados por el Tribunal Constitucional. Véase, por ejemplo, que el caso:

- Dé la oportunidad al Tribunal Constitucional para aclarar o cambiar su doctrina como consecuencia (...) del surgimiento de nuevas realidades sociales o de cambios normativos relevantes para la configuración del contenido de ese derecho o libertad fundamental [criterio b) de la STC 155/2009, de 25 de junio, FJ 2].

Atendiendo a este criterio, el caso cumplía esa relevante trascendencia constitucional que se exige a un recurso de amparo para ser admitido a trámite. Véase la LMH como un cambio normativo y la controvertida interpretación que la Sala 5. ${ }^{a}$ del TS ha hecho del art. 4.1 de la LMH; una interpretación, a nuestro juicio, ilegal y, en todo caso inconstitucional por ser contraria al derecho fundamental a la tutela judicial efectiva. Una interpretación contraria a la normativa vigente porque el art. 4.1 de la LMH establece que las declaraciones a que se refiere son plenamente compatibles con el ejercicio de las acciones a que bubiere lugar ante los tribunales de justicia. Y porque, como se explicará a continuación, la interpre-

43 OUBIÑA BARBOLLA, El Tribunal Constitucional: pasado, presente y futuro, Valencia, Tirant lo Blanch, 2012, pp. 408-420. Sobre el importantísimo valor que es estaría concediendo a la aquiescencia o negativa de jueces o magistrados que previamente hubieran conocido de la lesión, vid. AGUIAR DE LUQUE, Debate de los expertos sobre «El recurso de amparo constitucional: una propuesta de reforma» (autor: Fernández Ferreres), documento de Seminario y Jornada núm. 11/2005, Madrid, Fundación Alternativas, p. 21. A la inversa, la multiplicación de votos lo convertiría en inútil. Un pronóstico más exacto exigiría un seguimiento exhaustivo sobre su frecuencia. MOSCOSO DEL PRADO, «Debate de expertos», ob. cit., p. 30; ni LÓPEZ GUERRA, cit., p. 25. En lo que al informe favorable del Ministerio Fiscal se refiere ya dijimos en su día que creíamos que tendría escaso alcance a favor de la admisión. Y es que, bastaría remitirnos a la posición que el Ministerio Fiscal mantiene con carácter general en la fase de admisión del amparo constitucional (ya fuera e, incluso después de la reforma de 2007). Salvando las distancias, pueden existir tres indicadores que apoyarían nuestra posición: a) El Ministerio Fiscal, sólo ha interpuesto en treinta años 33 recursos de amparo; b) El Ministerio Fiscal siempre ha coincidido por lo general con el Tribunal Constitucional en que en más del 94\% (promedio de 1996-2006 antes de la reforma de 2007) de los amparos que se presentan están correctamente inadmitidos; y c) En los pocos casos en que no estaba de acuerdo e interpone recurso de súplica el motivo no era precisamente que la demanda no tuviese contenido constitucional, sino que discrepaba de otras cuestiones: la extemporaneidad, la falta de agotamiento de la vía judicial previa, etc. 
tación de la Sala $5 .{ }^{a}$ del TS en cuanto a la supuesta falta de un presupuesto objetivo para la revisión impide, como explicaremos a continuación y subrayó el voto particular del magistrado Javier Juliani en el ATS, de 21 de febrero de 2011, no sólo el acceso al proceso a la familia de Miguel Hernández, sino a cualquiera otra víctima sea cual fuera la circunstancia en que se sustente la solicitud de revisión.

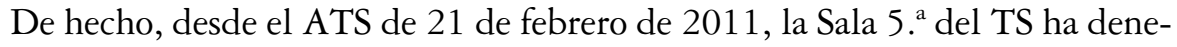
gado la petición de revisión de otras condenas de tribunales franquistas utilizando el mismo argumento. Véase por ejemplo, FJ 3 del ATS, Sala 5. del TS, sección 1. a de 30 de marzo de 2012 (RJ2012\8569), sobre la petición de revisión de la condena a muerte impuesta al doctor Calandre por el Consejo de Guerra Permanente de 18 de enero de 1940. También el ATS, Sala 5. . de 25 de marzo de 2011 (Roj: ATS 3951 2011), sobre la petición de revisión de la condena de 30 años de cárcel por un delito de adhesión a la rebelión impuesta a D. Gonzalo de la Fuente Muñoz por el Consejo de Guerra Permanente núm. 4 de Madrid el 15 de diciembre de 1942. Además de los argumentos que hemos visto hasta ahora, véase el voto particular discrepante del Magistrado D. Calvo Cabello ${ }^{44}$ (Roj: ATS 3951 2011) a este auto en donde defiendo que el Consejo de Guerra que le juzgó era un órgano ilegítimo, dependiente y parcial, lo que según el magistrado debía ser suficiente para declarar la nulidad radical de la condena impugnada.

- También cuando tenga origen en la interpretación jurisprudencial de la ley [criterio d) de la STC 155/2009, de 25 de junio, FJ 2).

En este punto, la trascendencia constitucional podría sustentarse en dos argumentos. Primero, la relevancia constitucional de la interpretación que la Sala 5. ${ }^{a}$ del TS hace de la LMH en el ATS de 21 de febrero de 2011 de la LMH y el candado que con esa interpretación se ha puesto a cualquier sucesiva revisión de una sentencia o resolución de entonces ${ }^{45}$.

Por otro lado, desde un punto de vista más general, los términos en que hasta la fecha se ha venido recogiendo el recurso de revisión en nuestras leyes procesales y la lectura que la jurisprudencia ha hecho del recurso de revisión. Y es que, como magníficamente expone IGARTÚA SALAVERRIA ${ }^{46}$ quizá haya-

${ }^{44}$ Sobre la petición de revisión de la condena de 30 años de cárcel por un delito de adhesión a la rebelión impuesta a D. Gonzalo de la Fuente Muñoz por el Consejo de Guerra Permanente núm. 4 de Madrid el 15 de diciembre de 1942

${ }^{45}$ Como se explicará con más detalle a continuación. Si bien es cierto que hasta el momento sólo conocemos que se haya aplicado la controvertida interpretación en el caso de Miguel Hernández.

46 IGARTÚA SALAVERRÍA, «¿Es preciso probar la inocencia en la revisión penal?», Diario La Ley, núm. 7532, Sección Tribuna, 21 de diciembre de 2010, Año XXXI, La Ley, disponible online en www.diariolaley.com, referencia la Ley 1387/2010. 
mos de reflexionar si la regulación legal y la interpretación jurisprudencial que se ha hecho hasta el momento invierte las reglas del juego del derecho a la presunción de inocencia (art. 24.2 CE). Y es que si resulta que es al promovente a quien corresponde probar la inocencia lo que se está haciendo es invirtiendo las reglas del juego; considerando como presupuesto y presunción de la que se parte a la culpabilidad en lugar de presumir y partir de la inocencia. En otras palabras, si lo que siempre ha habido que probar es la culpabilidad porque de la inocencia se parte, el tenor literal del precepto parece predisponer a lo opuesto; y eso, a salvo que se haga una lectura acorde con el 24.2 CE. Con ese prisma parece que la inocencia constituye la bipótesis a probar en lugar de ser la culpabilidad. Y no sólo ocurre así, sino que la intensidad y grado de la certeza también se cambia porque si antes había que probar la culpabilidad más allá de toda duda razonable, el legislador y la lectura del recurso de revisión parecen exigirlo a la inversa, lo que hay que probar más allá de la duda razonable es la inocencia.

Quizá en un futuro no muy lejano a la hora de volver sobre la proyectada reforma de la LECrim y, con ella, la del recurso de revisión haya que replantearse estas cuestiones. De hecho, basta remitirse a las versiones que se han barajado hasta ahora para advertir que el legislador quiere introducir cambios en este sentido. El Anteproyecto de LECrim de 31 de julio de 2011 preveía que cabría solicitar la revisión cuando después de la sentencia sobrevenga el conocimiento de nuevos bechos o nuevos elementos de prueba, que de haber sido conocidos bubieran determinado la absolución. E, incluso más allá de aquél, el texto más reciente adelantado por el Ministerio de Justicia actual propone que quepa, entre otros motivos, cuando después de la sentencia sobrevenga el conocimiento de hechos o elementos de prueba, que, de baber sido aportados, bubieran podido determinar la absolución o una condena menos grave.

- Cuando el asunto suscitado trascienda del caso concreto porque plantea una cuestión jurídica de relevante repercusión político-social (...) [criterio g) de la STC 155/2009, de 25 de junio, FJ 2).

El caso de Miguel Hernández cumpliría también, de acuerdo con este parámetro, la trascendencia constitucional para ser admitido a trámite y, por ende, resuelto en el fondo.

No hace falta explicar quién era Miguel Hernández, uno de los poetas más universales de la lengua española. Pero más allá de esta circunstancia, el asunto que se plantea trasciende sin duda del caso concreto de este insigne poeta porque otras víctimas del franquismo han solicitado la revisión de las sentencias condenatorias ante el TS al amparo de la LMH; y muchos de esos casos están todavía pendientes de resolución. Pero, además curiosamente, ha sido la Sala 5. a del TS quien con su interpretación ha subrayado la proyección del caso. La interpreta- 
ción de la Sala 5. ${ }^{a}$ del TS conduciría indefectiblemente a la exclusión de la revisión de cualquier sentencia a las que temporal y objetivamente se refiere la LMH; con independencia incluso de que el motivo de la revisión sea la LMH o un hecho nuevo (como ocurre en este caso), o cualquiera de otros motivos extraordinarios recogidos en la LECrim o en la LPM.

$\mathrm{Y}$ a este respecto es importante advertir también la trascendencia constitucional del caso por exigencias internacionales. Y es que el Derecho Internacional impone a los Estados deberes concretos en relación con la reparación de las víctimas de las violaciones graves de derechos humanos y del Derecho Internacional Humanitario. Deberes recogidos entre otros en los Principios y directrices básicos sobre el derecho de las víctimas de violaciones manifiestas de las normas internacionales de derechos humanos y de violaciones graves del derecho internacional bumanitario a interponer recursos y a obtener reparaciones, aprobados mediante la Resolución de la AGNU 60/147, de 16 de diciembre de 2005. En lo que aquí interesa, el principio 19 impone a los Estados la obligación de lograr, cuando sea posible, la restitución de la víctima a la situación anterior a la violación. En este sentido, el Estado español está obligado a adoptar aquellas medidas que hagan efectiva la restitución y, en el caso que ahora nos ocupa, ésta sólo es posible mediante una declaración de nulidad de la sentencia que condena para que así desaparezcan los efectos de dicha sentencia del ordenamiento jurídico, reponiéndose a la víctima a la situación jurídica anterior a la adopción de aquella.

\section{CONSIDERACIONES FINALES}

Hasta aquí hemos intentado realizar con mayor o menor fortuna un análisis crítico de la conclusión sobre la falta del presupuesto objetivo para solicitar la interposición del recurso de revisión que la Sala $5 .{ }^{a}$ del TS extrae de las declaraciones de la LMH.

El TS ha mantenido un criterio muy restrictivo ${ }^{47}$ en lo que a la revisión de las sentencias de condena dictadas durante la Dictadura y la Guerra Civil basadas

47 Vid. el caso de Ricardo Puente (STS, Sala 5. ${ }^{a} 19$ de febrero de 2007, estima la revisión); Caso Grimau (STS, Sala 5. a de 30 de enero de 1990, desestima la revisión); Caso Francisco Granado y Joaquín Delgado Martínez (STC 123/2004, de 13 de julio, estimó el amparo frente al ATS, Sala 5. ${ }^{a}$ de 3 de marzo de 1999); Caso Puig Antich (ATS, 13 de junio de 2003 denegando la autorización de la revisión); Caso Luis Casado (ATS, Sala 5. ${ }^{a}$ de 9 de julio, denegando la autorización de la revisión). Vid. ERRANDONEA, «Estudio comparado de la anulación de sentencias injustas en España», en Centro Internacional para la Justicia Transicional. Justicia, Verdad y Dignidad, disponible online en: http://ictj.org/sites/default/files/ICTJ-Spain-Amnesty-Justice-2008-Spanish_0.pdf 
en razones ideológicas, políticas o en creencias religiosas. A los recurrentes que antes de la LMH alegaban la CE como hecho nuevo el TS les decía que respecto de los hechos ocurrido antes de la CE, ésta sólo podría desplegar su valor sobre tales sentencias sólo sí sus efectos no habían expirado; incluso aunque en ellas estén comprometidos derechos fundamentales reconocidos ahora en la CE como el derecho a la tutela judicial efectiva o el derecho a un proceso con todas las garantías. Después de la LMH, la Sala 5. ${ }^{a}$ del TS utiliza el nuevo argumento de la supuesta falta del presupuesto objetivo para negar el acceso al proceso de revisión. El Tribunal Constitucional considera que en esa respuesta no hay lesión alguna de un derecho fundamental tutelable en amparo. En esta situación, parece evidente que nuestros dos altos tribunales se niegan a reconocer la superioridad axiológica del derecho democrático sobre el derecho no democrático.

Antes de terminar, es preciso volver a insistir en que ese nuevo razonamiento jurídico que hemos visto a través del ejemplo de la revisión de la condena solicitada por la nieta de Miguel Hernández repercute sobre cualesquiera otras sentencias de condena que durante la Guerra Civil y la Dictadura se produjeron únicamente por razones políticas, ideológicas, o de creencia religiosa. Y es que, de acuerdo con el nuevo argumento de la Sala $5 .{ }^{a}$ del TS da igual el motivo por el que se solicite la revisión de la sentencia porque falta en cualquier caso el presupuesto objetivo del proceso desde que la LMH haya declarado la injusticia e ilegitimidad de las condenas y los tribunales que las dictaron. En otras palabras cierra para siempre la puerta al proceso de revisión.

Por eso, habremos de seguir muy atentamente el camino y las respuestas que reciben los implicados. En este caso, la familia de Miguel Hernández, no dándose por vencida, ha recurrido ante el Comité de Derechos Humanos de la ONU (Ginebra) la providencia de inadmisión del recurso de amparo de la sección $4 .{ }^{a}$ del Tribunal Constitucional, así como las decisiones anteriores de la Sala 5. a del TS en lo que al incidente de nulidad de actuaciones se refiere y a la denegación de la autorización de la interposición del recurso de revisión de la sentencia que el 18 de enero de 1940 condenó a muerte a Miguel Hernández por un delito de adhesión a la rebelión. La familia también podría haber optado por recurrir ante el Tribunal Europeo de Derechos Humanos, pero después de haber consultado a varios expertos y siendo incompatibles ambas vías, ha optado por el Comité de Derechos Humanos de la ONU porque en éste el tema podría ser más novedoso y, porque una de las lenguas oficiales de trabajo es el castellano. 


\section{BIBLIOGRAFÍA}

AA. VV, «Encuesta», La reforma de la Justicia Constitucional, Cizur Menor, Thomson-Aranzadi/ CEJ, 2006, pp. 81-147.

AA. VV. «Debate de expertos» sobre «El recurso de amparo constitucional: una propuesta de reforma» (autor: FERNÁNDEZ FARRERES), documento de Seminario y Jornada núm. 11/2005, Madrid, Fundación Alternativas.

AA. VV. «Debate», La reforma de la Justicia Constitucional, Cizur Menor, ThomsonAranzadi/ CEJ, 2006, 149-197.

AA. VV. «Encuesta la reforma de la LOTC», TRC, núm. 18, 2006, pp. 11-76.

ARAGÜENA, «La ley de memoria histórica y sus limitaciones: una visión desde la óptica del derecho procesal», en Justicia de transición, justicia penal internacional y justicia universal (TAMARIT SUMALLA ed.), Barcelona, Atelier, 2010, pp. 119-141.

ASENCIO MELLADO, «La revisión de la condena del poeta Miguel Hernández».

CARRASCO DURÁN, Los procesos para la tutela judicial de los derechos fundamentales, Madrid, CEPC, 2002.

CORTES DOMÍNGUEZ, «El recurso de revisión», en Derecho Procesal Penal (MORENO CATENA, et. alii. GIMENO SENDRA, y CORTES DOMÍNGUEZ),

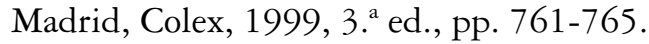

CRUZ VILLALÓN, «La réforme de la justice constitutionnelle espagnole», Die Ordung der Freibeit. Festschrift für Christian Starck zum siebzigsten Geburstag, Mohr Siebeck, Tübingen, 2007, 4. Teil - Rechtsvergleichung, ausländisches und internationales öffentliches Recht, pp. 72-728.

DE LA OLIVA SANTOS, Introducción al Derecho Procesal (con VEGAS TORRES y DÍEZ-PICAZO GIMÉNEZ, I.), Madrid, Editorial Centro de Estudios Ramón Areces S. A, 1999.

DOIG DÍAZ, «Análisis del nuevo incidente de nulidad de actuaciones en la Ley Orgánica 6/2007 de reforma del art. 241 LOPJ», Diario La Ley, núm. 6889, 22 de febrero, 2008, Año XXIX, ref. D-53, LA LEY 1116/2008, pp. 2-5.

ERRANDONEA, «Estudio comparado de la anulación de sentencias injustas en España», en Centro Internacional para la Justicia Transicional. Justicia, Verdad y Dignidad, disponible online en: http://ictj.org/sites/default/files/ICTJ-SpainAmnesty-Justice-2008-Spanish_0.pdf

ESCUDERO ALDAY ha hecho un seguimiento de los casos en diversos artículos en el diario Público, vid. 11 de octubre de 2012.

ESCUDERO ALDAY, «La declaración de ilegitimidad de los tribunales franquistas: una vía para la nulidad de sus sentencias», en Derecho y memoria bistórica (MARTÍN PALLÍN et. al. ESCUDERO eds.), Madrid, Trotta, 2007, pp. 222-229. 
ESCUDERO ALDAY, «Los tribunales españoles ante la Memoria Histórica: el caso de Miguel Hernández», en Hispania Nova. Revista de Historia Contemporánea, núm. 11, 2013, disponible en http://hispanianova.rediris.es.

ESCUDERO et. alii. CAMPELO, PÉREZ y SILVA, Qué hacemos por la Memoria Histórica, Madrid, Arkal, 2013.

ESPÍN TEMPLADO, «Los recursos constitucionales», La experiencia constitucional (1978-2000) (Trujillo Fernández, López Guerra, González-Trevijano dirs.), Madrid, CEPC, 2000, pp. 459-487

FERNÁNDEZ FARRERES, El recurso de amparo constitucional: una propuesta de reforma, Documento de trabajo 58/2004, Madrid, Fundación Alternativas.

GARTÚA SALAVERRÍA, «¿Es preciso probar la inocencia en la revisión penal?», Diario La Ley, núm. 7532, Sección Tribuna, 21 de diciembre de 2010, Año XXXI, La Ley, disponible online en www.diariolaley.com, referencia la Ley 1387/2010.

GÓMEZ COLOMER, «El recurso de revisión», Derecho Jurisdiccional, Proceso Penal (MONTERO AROCA et. alii. GÓMEZ COLOMER, MONTON REDONDO, BARONA VILAR), Tomo III, Valencia, Tirant lo Blanch, 2000, 9. ${ }^{a}$ Ed., pp. 392-398.

GUI MORI, «La modificación de la Ley Orgánica del Tribunal Constitucional. Profunda reforma del recurso de amparo y de la nulidad de actuaciones», Diario La Ley, núm. 6791, 2 octubre, Año XXVIII, ref. D-207, la Ley 5366/2007.

"JIMÉNEZ VILLAREJO ve "fraude de ley" en la decisión del Fiscal sobre Companys», El País, 26 de marzo de 2011.

«JIMÉNEZ VILLAREJO ve un "dislate” el fallo del Supremo sobre la condena de Miguel Hernández», El País, 25 de marzo de 2011;

MANJÓN-CABEZA OLMEDA, «2012: Las posibilidades legales de la Memoria Histórica», Revista Electrónica de Ciencia Penal y Criminología, Revista Electrónica de Ciencia Penal y Criminología, RECPC 14-12, Disponible en http://criminet. ugr.es/recpc/14/recpc14-12.pdf

MARTÍNEZ ARRIETA, «El recurso de revisión», en Recurso de casación y de revisión penal. Control de la presunción de inocencia», Valencia, Tirant lo Blanch, 2010, pp. 321-352, disponible en base de datos www.tiratnonline.com, referencias: TOL1.947.870.

MORENO CATENA, «El recurso de revisión», en El proceso penal, Valencia, Tirant lo Blanch, 2002, disponible en base de datos www.tirantonline.com, referencias epígrafes TOL100.449, TOL100.450, TOL100.451, TOL100.452, TOL100.453, TOL100.454, TOL100.455, TOL100.456.

OUBIÑA BARBOLLA, «Encuesta», La reforma de la Justicia Constitucional, Cizur Menor, Thomson-Aranzadi/ CEJ, 2006, p. 109; también en, El Tribunal Constitucional: pasado, presente y futuro, Valencia, Tirant lo Blanch, 2012. 
RIFA SOLER et. alii. VALLS GOMBAU, «El recurso de revisión», Derecho Procesal Penal, Madrid, Iurgium, 2000, pp. 310 y ss

SÁEZ VALCÁRCEL, "Justicia transicional y España ¿se puede juzgar la historia?», Memoria Histórica: ¿se puede juzgar la Historia?, Madrid, Asociación de Jueces para la Democracia/Fundación Antonio Carretero, 2010, pp. 85-119.

SORIANO GARCÍA, «La guerra de los dos Tribunales: una propuesta de paz (la necesaria reforma del recurso de amparo)», REDA-Civitas, núm.123, 2004, pp. 457-468.

TAMARIT SUMALLA, «Transition, Historical Memory and Criminal Justice in Spain», Journal of International Justice, Volume 9, Issue 3, 2011. Vid. también en «Justicia transicional y derecho penal en España», Memoria Histórica: ¿se puede juzgar la Historia?, Madrid, Asociación de Jueces para la Democracia/ Fundación Antonio Carretero, 2010, pp. 129-141.

TERRADILLOS BASOCO, «La revisión del pasado y la ley de la memoria histórica», La transformación jurídica de las dictaduras en democracias y la elaboración jurídica del pasado (MUÑOZ CONDE, et. alii. VORMBAUM, dirs.), Valencia, Tirant lo Blanch, 2009, pp.245-291.

TERRADILLOS BOSOCO, «La revisión del pasado y la Ley de Memoria Histórica», Revista penal, núm. 25, 2010, pp. 151-166.

VERGARA LACALLE, «La Ley de Memoria Histórica: ¿cuentas pendientes? Sobre la revisión judicial de las condenas dictadas por motivos políticos o sin las debidas garantías durante la Guerra Civil y la Dictadura», Justicia: revista de derecho procesal, núm. 2-4, 2011, pp. 177-230.

VICENTE BALLESTEROS, «La Ley de Memoria Histórica como motivo de revisión penal», Jueces para la democracia, núm. 74, 2012, pp. 70-82.

Title:

APPEAL BY REVIEW, CONSTITUTIONAL RELEVANCE AND HISTORICAL MEMORY

\section{Summary:}

1. Introduction. 2. Appeal by review and Historical Memory Law. 2.1. The appeal by review of Miguel Hernández's death sentence. A. Facts and request for appeal by review. B Prosecutor's opinion on the request for review. C. The response of the 5th Chamber of the Supreme Court. D. The incident of invalid proceedings. 2.2. The alleged lack of a legal preliminary requirement for apply a review by appeal and the Historical Memory Law. 3. An exam of the Supreme Court Order of 21st of February of 2011 from the perspective of fundamental rights. 3.1 The right to an effective judicial protection (due 
process) in its meaning of right to access to courts and the procedure and the rule for an interpretation favor actionis. 3.2 The right to an effective judicial protection in its aspect of the right to a decision based on law. 3.3 The right to be presumed innocent. 4. The background of this appeal by review; the facts and evidence put forward as new ones for the review of the sentence with res judicata effect. 5 The constitutional relevance of the appeal for the protection of a violation of fundamental rights. 6 Final considerations.

\title{
Resumen:
}

La posibilidad de revisar y, en su caso, declarar la nulidad de las sentencias del franquismo ha sido y, continua siendo, una cuestión muy controvertida política, doctrinal y también jurisprudencialmente.

Este trabajo analiza con ojos críticos el criterio mantenido recientemente por el Tribunal Supremo en esta materia al denegar la autorización para la interposición del recurso de revisión basándose en la supuesta carencia de objeto del recurso porque cuando la Ley de Memoria Histórica declara la injusticia e ilegitimidad de dichas condenas las priva de eficacia jurídica. Una respuesta que, como se explicará en las siguientes páginas, vulnera el derecho a la tutela judicial efectiva en dos de sus dimensiones concretas: el derecho de acceso al proceso y, el derecho a un resolución fundada en derecho; pero que afecta también indirectamente al derecho a la presunción de inocencia.

Una forma gráfica de presentar esta crítica es exponiéndola a través de un caso concreto; el de una víctima paradigmática del franquismo, el poeta Miguel Hernández y su familia a quienes inexplicablemente ambos tribunales les hayan cerrado las puertas.

\begin{abstract}
:
Appeal by review (revisión) against judgment, that has already gained res judicata, is an extraordinary remedy based upon reasons of Justice. When this appeal by review is used for the annulment of judgments of Franco dictatorship, this well known statement had been in the past, and has been nowadays, a very controversial issue politically, doctrinally and jurisprudentially.

This critical paper analyses the Spanish Supreme Court's opinion uphold in this matter to deny the previous authorisation, which is requiered for filing the petition of the appeal by review. The Supreme Court based its decision on a alleged lack of purpose for this review procedure because when the Historical Memory Law declares injustice and illegitimacy of those sentences, this Law deprives them also of their legal effect. This answer, as we explained in the following pages,
\end{abstract}


violates the due process (as a fundamental right of effective judicial protection) in two of its specific dimensions: the right of access to the courts and judicial procedure and the right to a decision based in law, but also indirectly affects the presumption of innocence.

In order to illustrate this review we decided to do it through a specific case, which involves a paradigmatic victim of Franco's regime, the poet Miguel Hernández and his family to whom the Spanish Supreme Court and the Constitutional Court have closed inexplicably their doors for Justice.

\section{Palabras clave:}

Recurso de revisión, nulidad de sentencias, recurso de amparo, trascendencia constitucional, violación de derechos fundamentales, Ley de Memoria Histórica, Miguel Hernández

\section{Key words:}

Appeal by review, annulment of judgement, appeal for constitutional protection, constitutional significance (Spanish writ of certiorari), Historical Memory Law, Miguel Hernández 
